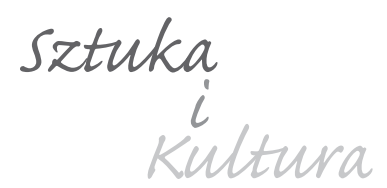

tom 1, 2013

jacek Tylicki

Johann Aken

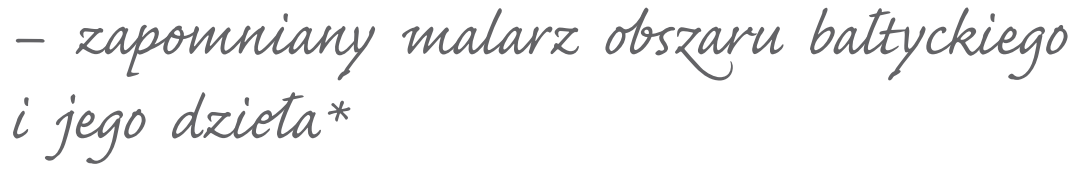

Od czasu publikacji przez inwentaryzatora Johannesa Heise w 1884 roku obrazu retabulowego Ecce Homo z ołtarza głównego w starym kościele w Helu (il. 1) ${ }^{1}$, malowidło to stało się rychło obiektem sporego zainteresowania, i to ze strony badaczy spoza kręgu lokalnego: już w 1906 roku wymienił je wybitny holenderski historyk sztuki Cornelis Hofstede de Groot ${ }^{2}$, ponownie w roku 1942 zajął się nim krótko inny tamtejszy znawca malarstwa Horst Gerson ${ }^{3}$, w 1957 roku wzmiankował je Wilhelm Reinhold Valentiner ${ }^{4}$, a stosunkowo niedawno napisał na jego temat kilka

* W gromadzeniu literatury estońskiej i wszechstronnych konsultacji przy przygotowywaniu niniejszego tekstu udzieliły mi pomocy Panie dr Pia Ehasalu oraz prof. Krista Kodres z Tallina, za co im w tym miejscu serdecznie dziękuję.

1 J. Heise, Die Bau- und Kunstdenkmäler der Provinz Westpreussen, t. 1: Pommerellen mit Ausnahme der Stadt Danzig, Danzig 1884-1887, s. 71.

2 C. Hofstede de Groot, Die Urkunden über Rembrandt, Den Haag 1906, nr 109, s. 136 n. Autor powołuje się również na bezpośrednie informacje dr. Ludwiga Kaemmerera, ówczesnego dyrektora poznańskiego oddziału Kaiser Friedrich-Museum.

3 H. Gerson, Ausbreitung und Nachwirkung der holländischen Malerei des 17. Jahrhunderts, Amsterdam 1983 (pierwodruk: Haarlem 1942), s. 505 („Danzig und Polen”).

4 W. R. Valentiner, Rembrandt and Spinoza. A Study of the Spiritual Conflicts in Seventeenth Century Holland, London 1957, s. 31; wzmiankę tę zauważył i roz- 
słów mieszkający w Holandii Gary Schwartz ${ }^{5}$. Powodem uwagi poświęconej dziełu przez autorów z jednego z najważniejszych centrów badań nad sztuką było użycie przez malarza ryciny Rembrandta jako pierwowzoru kompozycji ${ }^{6}$. Ten aspekt obrazu podkreślany był stale przez inne wymieniające go publikacje, zarówno sprzed 1945 roku, jak i po tym czasie ${ }^{7}$, gdy malowidło trafiło do gdańskiego Muzeum Pomorskiego, później przemianowanego na Muzeum Narodowe ${ }^{8}$. Niektórzy lokalni historycy utrzymywali wręcz, iż helskie dzieło wykonane zostało przez ucznia amsterdamskiego geniusza' ${ }^{9}$ Na poważniejsze rozważenie kwestii jego autorstwa wypadło

winął autor recenzji książki - Jan Białostocki, „Kunstchronik”, XI, 1958, z. 3, s. 78 n.; tu s. 79 , il. 4 .

5 G. Schwartz, Rembrandt, His Life, His Paintings: a New Biography, Harmondsworth 1985, s. 111. Autor ten błędnie przypisał autorstwo obrazu uwiecznionemu na nim herbem oraz monogramem fundatorowi, burmistrzowi Adrianowi von der Linde, nazywając go wyraźnie malarzem. Monogram „AVDLB” zidentyfikował jako oznaczający burmistrza (1610-1682) i fundację przezeń dzieła Heise 1884-1887, s. 71 - zob. też: przyp. 14.

6 Chodzi o akwafortę Chrystus przed Pitatem [Bartsch 77], datowaną przez autora w różnych stanach wykonania 1635 i 1636: Hollstein's Dutch and Flemish Etchings, Engravings and Woodcuts, vol. 18, Rembrandt van Rijn - text, oprac. C. White, K. G. Boon, Amsterdam 1969, vol. 19, s. 42; Rembrandt van Rijn - plates, oprac. C. White, K. G. Boon, Amsterdam 1969, s. 71.

7 Oprócz opracowań wymienionych w przyp. 1-5 i 8-9, zob. dawne inwentarze zabytków, publikowane pod nazwiskiem Georga Dehio: Handbuch der deutschen Kunstdenkmäler, II, Nordostdeutschland, Berlin 1906, s. 184; Handbuch der deutschen Kunstdenkmäler, II, Nordostdeutschland, Berlin 1926, s. 200; także Handbuch der deutschen Kunstdenkmäler, nowe oprac. E. Gall, Deutschordensland Preußen, oprac. przy współpr. B. Schmid, G. Tiemann, München 1952, s. 53 (ibidem, s. 9 - tom przygotowany w roku 1944). J. Heise, op. cit., s. 71, podaje, iż kompozycję Ecce Homo skojarzył z ryciną Rembrandta gdański rytownik, nauczyciel rysunku i miłośnik dawnej sztuki, Johann Carl Schultz (1801-1873).

8 J. Białostocki, M. Walicki, Rembrandt i jego krag, kat. wyst., Muzeum Narodowe w Warszawie, 15 III-30 IV 1956, s. 115, nr 60 (dzieło określone zostało wtedy jako znajdujące się w Muzeum Narodowym w Warszawie); A. Gosieniecka, Malarstwo gdańskie XVI i XVII wieku. Katalog wystawy, Muzeum Pomorskie w Gdańsku, Gdańsk 1957, s. 73, nr 96, il. 36 (malowidło już w Muzeum Pomorskim); M. Rostworowski, Pamięci Rembrandta - wystawa malarstwa polskiego $w$ trzechsetna rocznice śmierci artysty, Muzeum Narodowe w Krakowie, Oddział - Zbiory Czartoryskich, XII 1969, s. 7, 24, nr 93, il. 1; T. Grzybkowska, Andrzej Stech malarz gdański, Warszawa 1979, s. 115.

9 L. T. E. May, Festschrift zur Vierjahrhundertfeier der evangelischen Kirche und Gemeinde zu Hela, Hela 1925, s. 9 n. 
jednak poczekać aż do 1994 roku, kiedy toruński badacz Lech Brusewicz spróbował połączyć je z twórczością dość enigmatycznego Holendra działającego w Gdańsku, Helmicha van Twenhuysena ${ }^{10}$. Próbę wyodrębnienia przez Brusewicza grupy malowideł stworzonych przez tego malarza określić można jako niezbyt udaną. W jej składzie znalazł się obraz Ofiarowanie z Muzeum Warmii i Mazur w Olsztynie ${ }^{11}$, pochodzący raczej spod innej ręki niż Ecce Homo, ale też porównanie obu tych dzieł z jedyną dość pewną dziś pracą mistrza Helmicha, sygnowanym za pomocą monogramu portretem w Muzeum Narodowym we Wrocławiu (il. 2), nie skłania do przyznania racji autorowi. Wrocławski wizerunek cechuje bowiem - jak zauważył też Brusewicz - dość wysoka klasa artystyczna oraz rembrandtyzm widoczny w zakresie formy czysto malarskiej ${ }^{12}$, czym odróżnia się on korzystnie od helskiego przedstawienia, mającego z Rembrandtem związek głównie poprzez naśladownictwo kompozycyjne jego akwaforty ${ }^{13}$.

Nawiązując do wcześniejszych ustaleń Anny Gosienieckiej, Brusewicz powiązał jednak słusznie malowidło podarowane kościołowi w Helu w roku 1647 przez gdańskiego burmistrza Adriana von der Linde, którego herb i monogram na nim widnieją ${ }^{14}$, z Powrotem syna marnotrawnego z kaplicy św. Anny przy kościele św. Trójcy w Gdańsku, dawniej w retabu-

10 L. Brusewicz, Zagadka tzw. Ecce Homo z kościota św. Piotra na Helu - studium recepcji sztuki Rembrandta $w$ siedemnastowiecznej Rzeczypospolitej, „Acta Universitatis Nicolai Copernici, Zabytkoznawstwo i Konserwatorstwo", XXV, 1994, s. 59 n., zwł. s. 77-81. Autor ten zaproponował także - na podstawie literatury holenderskiej - inną nazwę sceny: Chrystus przed Pitatem (s. 66).

11 Ibidem, s. 79 n. Wcześniej malowidło to publikowane było w kat. wyst. Sztuka dawna w zbiorach muzeów województwa olsztyńskiego, Muzeum Warmii i Mazur, Olsztyn 1971, s. 30, nr 27, il. 24.

12 L. Brusewicz, op. cit., s. 80. Na temat wizerunku autorstwa Helmicha zob.: B. Steinborn, Katalog zbiorów malarstwa niderlandzkiego, Muzeum Narodowe we Wrocławiu, Wrocław 1973, s. 64, nr i il. 26 (bez identyfikacji malarza; Portret duchownego) oraz eadem, Katalog zbiorów malarstwa niderlandzkiego, Muzeum Narodowe we Wrocławiu, Wrocław 2006, s. 180 n., 341 n., nr i il. 61 (Portret dostojnika kościota wschodniego).

13 J. Białostocki, op. cit., s. 79, napisał, iż malowidło z Helu stanowi jeden z najwcześniejszych przykładów wpływu Rembrandta na wschodzie Europy, choć sam obraz jest niepiękny.

14 Herb określiła jako należący do burmistrza A. Gosieniecka, op. cit., s. 73, nr 96. L. Brusewicz, op. cit., s. 59, nazwał (nie bez racji) towarzyszący mu monogram „dziwnie skomponowanym" i próbował rozszyfrować go jako oznaczający skrót popularnej w krę- 
lum datowanego na 1650 rok ołtarza tamże (il. 3) ${ }^{15}$. Nie tylko naśladownictwo innej z rytowanych kompozycji Rembrandta ${ }^{16}$, ale i szczegóły malowania figur ludzkich, dość ciężkich i niezbyt biegle budowanych barwą, łączą to mniej znane dzieło z helskim Ecce Homo, które zresztą dziś znajduje się $\mathrm{w}$ umieszczonym $\mathrm{w}$ bezpośrednim sąsiedztwie kaplicy gmachu muzeum. Pierwotne pochodzenie dwóch prac tego samego autorstwa z nieodległych od siebie miejsc na jednym kulturowo obszarze istotnie sugerowało jako ich twórcę malarza lokalnego, gdańskiego, którego tożsamość musiała być jednak odmienna od wspomnianego tu Helmicha van Twenhuysen.

W swej notatce na temat obrazu helskiego, Hofstede de Groot wspomniał mimochodem - nie łącząc z nim tej pracy - o opierającym się na kompozycji tej samej ryciny Rembrandta malowidle w ratuszu w ówczesnym Rewalu, obecnie estońskim Tallinie, określając jako jego autora malarza „J. v. Aken"17. Napomknął za nim o tym także Brusewicz, identyfikując twórcę z amsterdamskim malarzem Janem van Aken (ok. 1614-1661) ${ }^{18}$. Odszukanie omówień i wizerunków tego obrazu przyniosło zaskakujące rezultaty. W sali rady czternastowiecznego ratusza $\mathrm{w}$ Tallinie znajduje się do dziś w istocie osiem malowideł (il. 4-11), umieszczonych w lunetach sklepiennych, przedstawiających - odpowiednio do lokalizacji - sceny biblijne

gach protestanckich sentencji „Verbum Domini manet in aeternum” (s. 73 n.), co już mniej przekonujące.

15 A. Gosieniecka, op. cit., s. 23, 73 n., nr 97, il. 37, umieściła tę pracę malarską obok omawianego tu Ecce Homo jako produkt „nieznanego malarza gdańskiego połowy XVII wieku"; L. Brusewicz, op. cit., s. 65, pisał raczej o wspólnocie poprzez autora kompozycji służących za wzór obu obrazom. Obecnie Powrót syna marnotrawnego zawieszony jest oddzielnie we wnęce północnej ściany kaplicy, nad drzwiami.

16 Pierwszoplanowa grupa postaci powtarza układ dwóch głównych figur $\mathrm{z}$ akwaforty o tym samym tytule [Bartsch 91], podpisanej przez Rembrandta w 1636 r. - Hollstein's..., t. 18 , s. 50 n.; t. 19 , s. 88 ; pozostałe elementy malowidła nie mają jednak odpowiedników w wymienionej rycinie.

17 C. Hofstede de Groot, op. cit., s. 137, nr 109; za nim powtórzył to H. Gerson, op. cit., s. 496 n., przy okazji "niderlandyzując” zupełnie nazwisko mistrza do formy "Jan v. Aken".

18 L. Brusewicz, op. cit., s. 62. Sugerując się błędnym zapisem nazwiska twórcy, jakie podał Hofstede de Groot, dokonał on nietrafnego utożsamienia z niderlandzkim mistrzem, posługując się pierwszym tomem leksykonu U. Thieme i F. Beckera (1907), w którym informacji o autorze malowideł w Estonii jeszcze brak. 
nawiązujące do tematu sprawiedliwości i jej egzekucji, opartych istotnie na rycinach Rembrandta, ale także wykonanych według przedstawień graficznych naśladujących dzieła Pietera Paula Rubensa, oraz według miedziorytów Matthäusa Meriana ${ }^{19}$. Z inskrypcji umieszczonych na jednym z tych obrazów wynika, iż wykonał je na miejscu w roku 1667 malarz Johann Aken. Pierwsze naukowe ich omówienie z 1904 roku $^{20}$ przyniosło poszukiwania archiwalnych informacji o artyście, w rezultacie których ustalono, iż jest on całkowicie inną osobą niż Holender Jan van Aken - w roku 1631 miał on przebywać w Gdańsku, w Rewalu pojawiając się dopiero w roku $1662^{21}$. Ta zachęcająca wiadomość skłania do porównania estońskiego cyklu z omówionymi wyżej malowidłami w mieście nad Motławą.

Bezpośrednia zależność zarówno omówionych wcześniej obrazów w Tallinie, jak i dzieł w Gdańsku od akwafort Rembrandta nie mogłaby stanowić wystarczającej podstawy do ich łączenia, gdyby nie fakt, iż forma czysto malarska wszystkich tych prac jest podobna. Wziąwszy nawet pod uwagę fakt, że malowidła ratuszowe ulegały późniejszym poprawkom², a dwa $\mathrm{z}$ nich mogą być uważane za dzieła warsztatowe ${ }^{23}$, wskazać trzeba na podobieństwa formalne obrazów w obu miastach, wykazujących w istocie przeciętną klasę artystyczną, ale niepozbawionych cech charakterystycz-

19 Pierwowzory graficzne kompozycji Akena w Tallinie wskazała po raz pierwszy dokładniej P. Ehasalu, Exempla docent ehk mónda Tallinna raesaali pildiprorammist ja rootsiaegsetest portreedest, „Kunsti-teaduslikke uurimusi”, XI, 2002, s. 165 n.; tu s. 183 n., choć już znacznie wcześniej wymieniano ogólnikowo oparcie kompozycji na grafice Rembrandta i według Rubensa - E. von Nottbeck, W. Neumann, Geschichte und Kunstdenkmäler der Stadt Reval, II, Die Kunstdenkmäler der Stadt Reval, Reval 1904, s. 191. Dla dwóch kompozycji - Samson i Dalila oraz Zuzanna przed sędziami nie zostały podane wzory; nie udało się ich odnaleźć także autorowi niniejszego tekstu.

20 Ibidem, s. 189 n.

21 Oparte na miejscowych archiwaliach (zob.: przyp. 25) dane na temat malarza wykorzystali pierwsi - wprawdzie bez cytowania źródeł - H. Peets, P. Johansen, Tallinna raekoda, Tallinn 1935, s. 8 . Na s. 8-10 podają oni szczegółowy opis dzieł malarskich $\mathrm{w}$ tamtejszym ratuszu.

22 List elektroniczny dr P. Ehasalu z Tallina do autora, 1 III 2011 r. - szczegóły zob.: nr kat. 5 .

23 Wskazywano na to kilkakrotnie w literaturze: w odniesieniu do obrazu Królowa Saby przed Salomonem - H. Peets, P. Johansen, op. cit., s. 9; Grosz czynszowy - Eesti kunsti ajalugu kahes köites, t. 1: Eesti kunst köige varasemast ajast kuni 19. saj. keskpaigani, red. B. Bernstein, E. Jansen [i in.], Tallinn 1975, s. 120; P. Ehasalu, op. cit., s. 180 n. 
nych. Kształtowanie figur ludzkich jest wszędzie dość podobne: postacie są potraktowane raczej malarsko, bez wyeksponowanego konturu, lecz słabo modelowane światłocieniem, nieco kukiełkowate w wyglądzie, o dość wysmukłych dłoniach, a fałdy ich szat układają się raczej grubo i stosunkowo schematycznie. W dziełach widoczna jest też predylekcja do przedstawiania w ogólnych zarysach wnętrz i detali architektonicznych. W gdańskich kompozycjach Ecce Homo i Powrót syna marnotrawnego postacie ludzkie mają formę bardziej linearną, a w szczegółach twarzy i ubioru przejawia się większa drobiazgowość. Jednak zarówno w pracach z Tallina, jak i Gdańska odnaleźć można porównywalne typy fizjonomiczne (np. głowa Chrystusa). Przeprowadzenie dobrych porównań detali obrazowych jest utrudnione przez fakt, że prace malarza - zwłaszcza te estońskie - ulegały kilkakrotnym restauracjom, które po części można utożsamiać z przemalowaniami.

Kolorystyka jest zawsze podobna, ciepła z dużym udziałem czerwieni i dość ciemna, zgodnie z praktyką maniera tenebrosa, powszechną w późniejszym XVII stuleciu. Widoczne są też podobieństwa w uchybieniach - błędach perspektywicznych i konstrukcji rysunkowej postaci, choć przejawiają się one w poszczególnych dziełach w różnym stopniu. Należy wreszcie wspomnieć o zbliżonej formie liter, obecnych obficie na malowidłach ratuszowych w Tallinie, ale także na obrazie Ecce Homo wykonanym dla kościoła w Helu.

Dalszą przesłanką do łączenia obrazów z Gdańska i Tallina jest wspomniany już fakt, iż Johann Aken mieszkał wcześniej w pierwszym z tych miast. Informują o tym dwa zachowane w archiwum w Tallinie obszerne dokumenty (akta rozprawy sądu wójtowskiego tego miasta) (il. 12), które wykorzystano w piśmiennictwie po raz pierwszy w 1935 roku $^{24}$, a z których wynika, iż przybyły do Rewala około początku roku 1662 artysta oskarżany był o pozostawienie w Gdańsku poślubionej tam w 1631 roku żony, aby w nowym miejscu zawrzeć związek z inną kobietą. Oskarżenia te, wysuwane przez niechętnych przybyszowi mistrzów cechowych, okazały się - na podstawie zasięgniętej w Gdańsku informacji - bezpodstawne ${ }^{25}$. Sam

24 Zob. przyp. 21.

25 Tallinna Linnaarhiiv, B.230, Der Revaler Magistrat, Bf 33-III, Gilden und Gewerke, Handwerksämter, Maler 1619-1699, k. 79 n. (nowej paginacji). List z oskarżeniem mala- 
Aken pożegnał się z tym światem w roku 1689 i został pochowany w południowej nawie kościoła św. Piotra w Rydze, gdzie w 1943 roku odnaleziono jego nagrobek ${ }^{26}$. Pomimo wymienienia we wspomnianym przed chwila źródle archiwalnym prac malarza dla ratusza oraz lokalnej szlachty i mieszczaństwa, jakichkolwiek dalszych informacji pisanych o jego działalności na terenie dzisiejszej Estonii czy też Łotwy brak ${ }^{27}$. W literaturze pojawiła się wiadomość na temat jeszcze jednego malowidła w Estonii, przypisywanego Akenowi, mianowicie Grosza czynszowego w Państwowym Muzeum Sztuki w Tallinie; jego istnienia nie udało się jednak potwierdzić2 ${ }^{28}$.

Znana jest natomiast wzmianka z 18 października 1656 roku w archiwach Lubeki, informująca o tym, że artysta ochrzcił wtedy - w tamtejszym kościele Mariackim - swego syna ${ }^{29}$. Przeprowadzkę Akena do tego ośrodka łączyć można z rozpoczętą rok wcześniej w Rzeczypospolitej drugą wojną szwedzką; śladów jego uprawianej w nim twórczości, ani też dalszych zachowanych tam dokumentów dotyczących artysty nie udało się jednak odnaleźćc ${ }^{30}$. Następnym niewyjaśnionym aspektem życia twórcy jest

rza wystosowany został 6 XII 1662 r., zaś dokumenty dotyczące sprawy z towarzyszącymi aneksami datowane są od 26 I do 13 IV 1663 r. Najobszerniejszą do tej pory informację o źródle podała K. Kodres, Tallinna maalijad 17. ja 18. sajandil, „Kunsti-teaduslikke uurimusi", VII, 1994, s. 134 n.; tu s. 143, nr 14.

26 Nagrobek (nr 42) odnaleziono w zimie 1943 r. po spaleniu kościoła 29 VI $1941 \mathrm{r}$. - P. Campe, Lexikon liv- und kurländischer Baumeister, Bauhandwerker und Baugestalter von 1400-1850, II. Teil: Nachtrag und Ergänzung zum 1. Bande, Stockholm 1957, s. 59. Wiadomość o miejscu pochowania artysty pochodzi od prof. A. Tuulso (1944).

27 List elektroniczny dr. P. Ehasalu do autora, 26 I 2011 r.; list elektroniczny dr. O. Sparitisa z Rygi do autora, 13 III 2011 r.

28 Eesti kunsti..., s. 120. Obecnie dzieło takie nie jest w muzeum znane - list elektroniczny H. Upan do autora, 13 VI $2011 \mathrm{r}$.

29 Archiv der Hansestadt Lübeck, 06.1-1, St. Marien Taufbuch, 1641-1658, s. 428: 18 [8br. 1656] Johann Ake, Mabler Zu Dantzig / Jochim Detleffs / hanß Knake / Katharina Siemßen [rodzice chrzestni]. Imienia dziecka w dokumencie brakuje; fakt, iż chrzczony był syn, wynika ze zwyczaju powołania dwóch męskich osób w grupie trzech rodziców chrzestnych (list elektroniczny J. Müller z archiwum lubeckiego do autora, 28 IV 2011 r.). Wzmiankę źródłową odnotowuje w druku po raz pierwszy P. Ehasalu, op. cit., s. 181.

30 List elektroniczny dr. H. Vogeler z St. Annen-Museum w Lubece do autora, 27 I 2011 r.; list elektroniczny J. Müller z archiwum lubeckiego do autora, 9 II 2011 r. Malarz przebywał może w Lubece przejściowo, gdyż już w XIX w. tamtejszy archiwista Eduard Hach (1841-1917) odnotował w swych zapiskach, że jego nazwiska brak w urzę- 
jego niderlandzkie pochodzenie, które sugerowano w literaturze ${ }^{31}$. Choć supozycja ta nie jest pozbawiona podstaw - w słownikach notowanych jest bowiem kilku tamtejszych artystów o podobnym brzmieniu nazwisk ${ }^{32}$, Aken zaś stale używał rycin utrwalających kompozycje dwóch najbardziej chyba znanych przedstawicieli malarstwa z obu części siedemnastowiecznych Niderlandów - nic jednak pewnego dotąd nie wiadomo na temat młodości i wyszkolenia mistrza ${ }^{33}$.

$\mathrm{Na}$ tym tle zaskakuje również zupełny brak informacji o Akenie w gdańskiej literaturze i źródłach pisanych ${ }^{34}$; na pewno nie jest on wymieniony w miarodajnej kronice cechu malarzy autorstwa Falckenbercka z 1724 roku $^{35}$. Oznacza to, iż artysta działał poza tą organizacją jako wolny mistrz; taka pozycja umożliwiała mu być może łatwiejszą zmianę miejsc

dowych dokumentach miejskich - Archiv der Hansestadt Lübeck, 05.5, Sammlung Eduard Hach (Erwerb Alt/2), nr 100, Blatt Johann Ake.

31 H. Peets, P. Johansen, op. cit., s. 8 i autor słownika Художники народов СССР. Биобиблиографический словарь, т. 1: Аавик-Бойко, сост. О. Э. Вольценбург, Москва 1970, s. 73, piszą o możliwym wyszkoleniu twórcy w Niderlandach; E. Savinova, Aken, Johann (van ?), [w:] Saur allgemeines Künstler-Lexikon. Die bildenden Künstler aller Zeiten und Völker, t. 1: A-Alanson, München 1992, s. 700 - już o jego przypuszczalnym niderlandzkim pochodzeniu. Wskazywano też na wpływy Holandii i Flandrii w samej sztuce malarskiej Akena (История искусства народов СССР, t. 4: Искусство конща XVII-XVIII веков, red. А. Ю. Нурок, М. А. Орлова, [Москва] 1976, s. 346). Zob. też przyp. 17.

32 Choćby w najnowszej uniwersalnej publikacji tego typu - Saur allgemeines..., s. 699 n.; zob. też przyp. 18. „Aken” oznacza w języku niderlandzkim Akwizgran, a zatem możemy mieć tu do czynienia istotnie z nazwiskiem toponimicznym o genezie niderlandzkiej.

33 W literaturze podkreślano jednak fakt, że rodzina o identycznym nazwisku występuje już w XVI w. w Rewalu i na terenie Inflant - E. v. Nottbeck, W. Neumann, op. cit., s. 191; Lexikon baltischer Künstler, red. W. Neumann, Riga 1908, s. 1. Nie wiadomo, czy z tej samej rodziny pochodził Hans von Aken, rzeźbiarz działający w Tallinie pod koniec XVI stulecia - zob. nр.: Художники народов..., s. 73.

34 Brak tego nazwiska w najnowszej publikacji leksykograficznej, opartej szeroko na źródłach - J. Pałubicki, Malarze gdańscy. Malarze, szklarze, rysownicy i rytownicy w okresie nowożytnym $w$ gdańskich materiatach archiwalnych, t. 2: Stownik malarzy, szklarzy, rytowników i rysowników, Gdańsk 2009.

35 Archiwum Państwowe w Gdańsku, 300, C/613 (C. F. von Falckenberck, Das Große MeisterBuch Darinnen Die Jenigen in Ziemliche Richtiger Ordnung stehen, So dem Kunstliebenden Gewerck Der Mabler und Conterfäyer, sind Einverleibet worden..., 1724). Rękopis Falckenbercka był jedną z podstaw źródłowych publikacji J. Pałubickiego (zob. przyp. 34). 
zamieszkania. W odróżnieniu od Gdańska, w którym twórca został do XIX wieku - okresu powstawania literatury dotyczącej sztuki - najwyraźniej zupełnie zapomniany, dobrze czytelna sygnatura Akena na malowidle Samson $i$ Dalila w ratuszu w Tallinie wywołała liczne wzmianki na jego temat w cytowanej w niniejszym tekście literaturze lokalnej, poczynając od przełomu XIX i XX wieku. Trzeba jednak zauważyć, że tamtejsze informacje dotyczące malarza i jego dzieł bywały często powtarzane.

Sygnalizowane wyżej kłopoty z identyfikacją postaci artysty w gdańskich archiwaliach nie wykluczają istnienia dalszych jego dzieł na tym terenie. Wydaje się też, iż można pokusić się o przypisanie mu zespołu dziewięciu malowideł ze stropu pokoju burmistrza w ratuszu staromiejskim w Gdańsku (il. 13-15), dawniej zdobiących sień kamienicy mieszczańskiej, należącej do rodziny Fichtel ${ }^{36}$, a także obrazów w ołtarzu Czterech Doktorów Kościoła w katedrze w Oliwie, z których uwagę zwraca zwłaszcza retabulowe Nawiedzenie (il. 16) ${ }^{37}$. W wypadku, silnie niestety przemalowanych, malowideł stropowych o wydźwięku religijnym, pasyjno-doksologicznym, można stwierdzić typowe dla Akena wzorowanie się na rycinach wykonanych na podstawie kompozycji Rembrandta i Rubensa (a także van Dycka i Palmy młodszego) ${ }^{38}$; jedna z mniej uszkodzo-

36 W egzemplarzu publikacji: A. Schmidt, Danziger merkwürdige Inschriften, Danzig 1925 [„Heimatblätter des Deutschen Heimatbundes Danzig”, II, 1925, z. 2], w Bibliotece Gdańskiej PAN jako właściciel tego domu przy Altstädtischer Graben 69/70 (Podwale Staromiejskie) określony jest odręcznie Johann Conrad Fichtel w miejsce skreślonej drukowanej informacji o rajcy Georgu Fichtlu (s. 34, nr 124). J. Habela, Ratusz Staromiejski w Gdańsku, Wrocław 1975, s. 42, uzupełnia, iż kamienica należała później do rodziny Grunau.

37 Malowidła te były już w XIX wieku kilkakrotnie określane jako piękne i wybitne (J. C. Kretzschmer, Geschichte und Beschreibung der Cisterzienser-Abtei Oliva, Danzig 1847, s. 45 n.; T. Hirsch, Das Kloster Oliva. Ein Beitrag zur Geschichte der Westpreußischen Kunstbauten, Danzig 1850, s. 58; J. Heise, op. cit., s. 120). T. Hirsch, op. cit., podjął próbę przypisania tego obrazu oraz malowidła Chrystus wręczający klucze św. Piotrowi w retabulum ołtarza św. Józefa w transepcie katedralnym Adolfowi Boyowi, co powtarzali kolejni autorzy piszący o świątyni oliwskiej.

38 Na wymienione w niniejszym tekście wzory graficzne wskazała w swej pracy J. Kowalkowska, Strop ramowy z Sali Burmistrza w Ratuszu Staromiejskim w Gdańsku, Gdańsk 2009 [mps pracy licencjackiej pod kierunkiem dr. Jacka Kriegseisena, Katedra Historii Sztuki UG], s. 15 n. W stosunku do jej ustaleń można wprowadzić następujące uzupełnienia i uwagi: Ostatnia wieczerza wzoruje się na rycinie Rubensa, a nie na malowidle samego mistrza; do Chrystusa przed Annaszem nie udało się odnaleźć pierwowzoru także 
nych kwater, Niesienie krzyża, pozwala też jednak rozpoznać w niej cechy ręki malarza - zarówno pod względem typów fizjonomicznych, jak i sposobu budowania figur kolorem i światłocieniem. Stosunkowo gładkie tu i słabo modelowane oblicza postaci dają się porównać z niektórymi odpowiednikami z Tallina oraz retabulum oliwskiego. Wchodząca w skład cyklu kompozycja Skazanie Chrystusa na śmierć powtarza ponownie rembrandtowską rycinę B. 77 , zastosowaną w jednym z malowideł zespołu z Tallina i w Ecce Homo z Muzeum Narodowego w Gdańsku; podobna jest też forma jej trawestacji. Omawiany cykl datować można na lata czterdzieste XVII stulecia ${ }^{39}$. Z kolei oliwskie Nawiedzenie, które dzięki umieszczonej na strukturze kamiennego ołtarza dacie można określić jako pochodzące z roku 1645, jest - mimo uszkodzeń przez owady - stosunkowo dobrze czytelne w pierwotnej formie, która nie tylko pozwala atrybuować je według formy malarskiej i detali, ale daje też pojęcie o nie najgorszych umiejętnościach twórcy w zakresie obrazowania roślinności, która wśród innych jego dzieł, bardziej czytelna jest tylko w Powrocie syna marnotrawnego. Jeśli chodzi o wzór graficzny, tym razem kompozycja jest przetworzoną kopią drzeworytu Albrechta Dürera z około 1504 roku $^{40}$.

Należy wyrazić nadzieję, że niniejsza próba wstępnego zebrania wiadomości na temat nieznanego dotąd polskiej historii sztuki malarza, uro-

autorowi niniejszego tekstu; wzory Dürera i Goltziusa w wypadku Chrystusa przed Kajfaszem są wątpliwe, natomiast postać arcykapłana w tej kompozycji istotnie powiela figurę Saula z malowidła Rembrandta Dawid grajacy przed Saulem (ok. 1630), które nie było powielane w grafice, tak więc malarz mógł korzystać z kopii rysunkowej; Cierniem koronowanie - rycinę według van Dycka wykonał Schelte a Bolswert; Upadek Chrystusa pod krzyżem - wzór w formie szkicu rysunkowego Rubensa nie jest przekonujący, innych zaś nie udało się odnaleźć; Śmierć Chrystusa na krzyżu prawdopodobnie oparta jest na rys. wg malowidła mistrza, a wskazywanie na inne szczegółowe wzorce w tej kompozycji jest wobec rozpowszechnienia tematu wątpliwe; Zmartwychwstanie dość dokładnie powtarza nie malowidło Rubensa, lecz kopiującą je rycinę Scheltego a Bolswert, zaś dodatkowy wzór Cornelisa Corta nie wydaje się prawdopodobny.

39 A. Schmidt, op. cit., s. 34, nr 124 wspomina o dacie „1642” umieszczonej na ozdobnej listwie, będącej częścią wyposażenia przeniesionej do ratusza izby, niemającej jednak bezpośredniego związku z malowidłami stropowymi.

40 The Illustrated Bartsch, 10, formerly vol. 7 (part 1), Sixteenth Century German Artists, Albrecht Dürer, red. W. L. Strauss, New York 1980, s. 179, nr 84 (132); 10 (Commentary), red. W. L. Strauss, New York 1981, s. 356 nr 284 [B. 84 (132)]. 
dzonego zapewne około 1610 roku, poruszającego się w obrębie ważnych ośrodków sztuki obszaru bałtyckiego, przyniesie z czasem dalsze istotne informacje na jego temat. Szczególnie ważne wydaje się znalezienie odpowiedzi na pytanie, z jakich przyczyn twórca dość przeciętnie uzdolniony i nieodbiegający tematyką swych realizacji od typowego $w$ regionie repertuaru posługiwał się w tak znacznym stopniu - obok wykorzystywania innych, dość rozpowszechnionych wzorców graficznych północnoeuropejskich mistrzów - aktualnymi rycinami najbardziej może nowatorskiego ówcześnie artysty europejkkiego, Rembrandta van Rijn, a nawet rysunkowymi kopiami jego malowideł.

\section{Katalog prac}

Przyjęty został alfabetyczny układ haseł według miejsc przechowywania obrazów; wykaz skrótów odnoszący się do cytowanej literatury jest zalączony na końcu katalogu.

1a-b. Zespół dwóch malowideł ołtarzowych: Powrót syna marnotrawnego - retabulum; Chrystus w Ogrójcu - górna kondygnacja, Gdańsk, kaplica św. Anny, ok. 1650

Powrót częściowo według ryciny Rembrandta (B. 91)

Olej, deska, obraz retabulowy - $165 \times 98 \mathrm{~cm}$ [Gosieniecka 1957]; obraz górny - ok. $65 \times 95 \mathrm{~cm}$. Powrót syna marnotrawnego obecnie zawieszony we wnęce nad drzwiami wejściowymi w ścianie północnej; Chrystus $w$ Ogrójcu w miejscu pierwotnym.

Niesygnowane, niedatowane.

Powrót... do 1945 roku w retabulum ołtarza kaplicy, umieszczonego tam około połowy XVII stulecia [Schmidt 1901; Drost/Swoboda 1972]. W nieznanym okresie po II wojnie światowej - być może w związku z wystawą 1957 roku - wyodrębniony (w ołtarzu w jego miejscu obecnie kopia obrazu Matki Boskiej Ostrobramskiej).

Wystawy: Muzeum Pomorskie w Gdańsku, 1957 (obraz retabulowy).

Lit.: Schmidt 1901, s. 54, il.; Dehio/Gall 1952, s. 22; Gosieniecka 1957, s. 23, 73 n., nr 97, il. 37; Drost/Swoboda 1972, s. 71, il. 57; Grzybkowska 1979, s. 115; Brusewicz 1994, s. 65. 
2. Ecce Homo (Chrystus przed Pitatem), Gdańsk, Muzeum Narodowe, 1647 Według ryciny Rembrandta (B. 77)

Olej, deska, $235 \times 200 \mathrm{~cm}$ [Gosieniecka 1957], depozytowy nr inw. w Gdańsku MNG/SD/76/ MD (dawniej DM/193), warszawski nr inw. MNW 210863 [informacje Magdaleny Mielnik z MNG; Rostworowski 1969].

Niesygnowany. Na cokole kolumny po lewej herb rodziny gdańskiej von der Linde. Na przeciwległym cokole kolumny, po prawej, monogram „A[drian] $\mathrm{V}$ [on] - D[er] L[inde] B[ürgermeister]” („A” i „V” w ligaturze); w jego dolnej części data „16-47”. Górą i dołem, poza przestrzenią obrazową, typologicznie dobrane inskrypcje, odpowiednio ze Starego i Nowego Testamentu: „Die Strafe Liget Auf Ihm Das Wir Friede Hetten / Vnd Dvrch Seine Wunden Sindt Wir Geheilet: Esai 53.” oraz „Gott Hat Den Der Von Keiner Sünde Wuste Fvr Vns Zvr Sünde Gemacht / Avf Das Wir Würden In Im Die Gerechtigkeit Die Fvr GotT Gilt: 2 Corinth: 21".

Fundowany wraz z ołtarzem do kościoła w Helu przez burmistrza gdańskiego Adriana von der Linde [Heise 1884-1887]. Po II wojnie światowej w Muzeum Narodowym w Warszawie - wtedy w złym stanie zachowania [Białostocki/Walicki 1956], następnie - od 1956 roku - jako depozyt w Muzeum Pomorskim, późniejszym Muzeum Narodowym w Gdańsku [Gosieniecka 1957; informacje Magdaleny Mielnik z MNG].

Restaurowany w latach 1731 i 1908, w tym ostatnim wypadku przez prof. Wilhelma Stryowskiego w Gdańsku [May]. Ponownie zapewne odnowiony w latach 1956-1957.

Wystawy: Muzeum Pomorskie w Gdańsku, 1957; Muzeum Narodowe w Krakowie, Oddział - Zbiory Czartoryskich, grudzień 1969.

Lit.: Heise 1884-1887, s. 71; Hofstede de Groot 1906, s. 136 n., nr 109; Dehio 1906, s. 184; May 1925, s. 9 n., il.; Dehio 1926, s. 200; Gerson 1942/83, s. 505; Dehio/Gall 1952, s. 53; Białostocki/Walicki 1956, s. 115, nr 60; Gosieniecka 1957, s. 73, nr 96, il. 36 (malowidło już w Muzeum Pomorskim); Valentiner 1957, s. 31; Rostworowski 1969, s. 7, 24, nr 93, il. 1; Grzybkowska 1979, s. 115; Schwartz 1985, s. 111; Brusewicz 1994.

3. Zespół dziewięciu malowideł stropowych, Gdańsk, Ratusz Staromiejski, I piętro, dawny pokój burmistrza, 1642 (?)

Wszystkie dzieła olej, płótno [Guć-Jednaszewska 1992], wymiary maksymalne całości stropu $637 \times 516 \mathrm{~cm}$ [Kowalkowska 2009].

Niesygnowane, niedatowane [Kowalkowska 2009]. 
Około 1914 roku malowidła przeniesione na obecne miejsce wraz z innymi elementami wyposażenia z domu Johanna Conrada Fichtla, następnie Grunauów, przy ul. Podwale Staromiejskie 69/70, gdzie pierwotnie zdobiły kaplicę [Schmidt 1925; Habela 1975]. Na będącej częścią wyposażenia listwie widoczna data „1642” [Schmidt 1925].

Prawdopodobnie przystosowane do nowego pomieszczenia w czasie przenosin z naruszeniem oryginalnej struktury stropu [Kowalkowska 2009]. Restaurowane po uszkodzeniach wojennych w 1964 roku przez Antoniego Mironowskiego; w 1986-1987 ponowna restauracja dwóch malowideł, Ztożenia do Grobu i Chrystusa przed Annaszem, w gdańskim oddziale Pracowni Konserwacji Zabytków pod kierownictwem Barbary Grabowskiej [Guć-Jednaszewska 1992; Kowalkowska 2009].

a. Ostatnia Wieczerza, według kompozycji Rubensa i ryciny Boëtiusa a Bolswert

$203 \times 259 \mathrm{~cm}$.

b. Chrystus przed Annaszem

$179 \times 122 \mathrm{~cm}$.

c. Chrystus przed Kajfaszem, częściowo według kompozycji Rembrandta Dawid grajacy przed Saulem (Frankfurt nad Menem)

$167 \times 227 \mathrm{~cm}$.

d. Cierniem koronowanie, według kompozycji Anthonisa van Dycka i ryciny Scheltego a Bolswert oraz kompozycji Rubensa i ryciny Paulusa Pontiusa Tomyris z gtową króla Cyrusa

$135 \times 158 \mathrm{~cm}$.

e. Skazanie Chrystusa na śmierć, według ryciny Rembrandta (B. 77) oraz kompozycji Jacopo Palmy ml. i ryciny Aegidiusa Sadelera Biczowanie Chrystusa

$69 \times 227 \mathrm{~cm}$.

f. Upadek Chrystusa pod krzyżem

$133 \times 155 \mathrm{~cm}$.

g. Śmierć Chrystusa na krzyżu, według kompozycji Rubensa Przebicie Chrystusa na krzyżu wtócznią (Antwerpia)

$181 \times 229 \mathrm{~cm}$.

h. Ztożenie Chrystusa do grobu, według kompozycji Rubensa i ryciny Jana Witdoecka

$177 \times 120 \mathrm{~cm}$.

i. Zmartwychwstanie, według kompozycji Rubensa i ryciny Scheltego a Bolswert

$183 \times 227 \mathrm{~cm}$. 
Lit.: Schmidt 1925, s. 34, nr 124; Habela 1975, s. 42 i przyp. 161, il. 111; Habela 1986, s. 27; Guć-Jednaszewska 1992, s. 21 i przyp. 20; Brusewicz 1994, s. 64 n.; Kowalkowska 2009.

4a-b.Zespół dwóch malowideł ołtarzowych: Nawiedzenie św. Elżbiety - retabulum; Chrystus jako król świata - górna kondygnacja, Gdańsk-Oliwa, katedra, ołtarz Czterech Doktorów Kościoła, 1645

Nawiedzenie częściowo według ryciny Dürera

Olej, deska, obraz retabulowy $-115 \times 81 \mathrm{~cm}$ [inf. Alina Szpakiewicz z Muzeum Archidiecezjalnego Gdańsk-Oliwa]; obraz górny - ok. $53 \times 42 \mathrm{~cm}$. Umieszczone w pierwszym od strony nawy północnej ołtarzu w obejściu. Fundowane wraz z ołtarzem przez opata oliwskiego Aleksandra Kęsowskiego w 1645 roku (herb, inicjały i data widoczne na ołtarzu).

Obraz retabulowy przemalowany przed połową XIX wieku [Hirsch 1850], następnie restaurowany w okresie 2008-kwiecień 2011 przez Beatę Sobieszek-Nieścior [inf. Alina Szpakiewicz z Muzeum Archidiecezjalnego Gdańsk-Oliwa].

Lit.: Kretzschmer 1847, s. 45 n.; Hirsch 1850, s. 58; Heise 1884-1887, s. 118 n.; Mamuszka/Stankiewicz 1959, s. 40; Mamuszka 1985, s. 129; Lingenberg 1986, s. 187; Iwicki 1994, s. 76 n., nr 18, il. 36; Bogdanowicz 1995, s. 80 n.; Iwicki 2001, s. 66 n., nr 18.

5. Zespół ośmiu malowideł w lunetach sklepiennych, Tallin, Ratusz, Sala Rady, ściana południowa, 1667

Wszystkie dzieła olej, płótno, ca $264 \times 252 \mathrm{~cm}$ [inf. Pia Ehasalu, Tallin]. Według inskrypcji na malowidłach Herodiada $z$ gtowa św. Jana Chrzciciela oraz Samson i Dalila, fundowane przez podkomorzych miejskich Hinricha Bahde i Constansa Corbmachera; na obrazie Samson i Dalila sygnowane i datowane 1667.

Malowidła restaurowane przynajmniej trzy razy; po raz pierwszy „Abwaschung” wykonał już w roku 1689 miejscowy malarz Hans Beckmann, następne znane prace w latach trzydziestych XX wieku [inf. Pia Ehasalu, Tallin]. Restauracja 1971-1975 upamiętniona rzeźbioną inskrypcją na ramie przy kompozycji Grosz czynszowy.

a. Herodiada z gtowa św. Jana Chrzciciela (I półluneta) - częściowo według kompozycji Rubensa i ryciny Scheltego a Bolswert

U dołu obrazu inskrypcja komentująca oraz początkowa część napisu fundacyjnego z datą: „Ob gleich der teure Mann Johannes hie muß büßen, Die Warheit mit dem Kopff, vor Herodias Füßen / So hat den 
noch gewiß Herodes böß gethan, Das Er des Brüdern Weib ehlich genommen an / Im IAHr, 1667, als Herr Hinrich Bahde VNd Herr Constans Corbmacher Dieser Stadt Kemmer Herren Waren, Ist Dvrch Deren".

b. Samson i Dalila (II półluneta)

U dołu obrazu inskrypcja komentująca oraz końcowa część napisu fundacyjnego wraz z sygnaturą: „Hatt Simson nicht zuvorn mit Tausenden gekempffet. Alhie Er aber wird durch Weiber List gedempffet, / Fragst, ob er auch hab schuldt; Ja, weil Er nachgesagt. Waß Er verschweigen solt Drumb stirbt Er vnbeklagt / Befordervng Diess Rahthavs Renoviret, Vnd Diese Stvcke Gemahlet Woreden Von iohan aken".

c. Zuzanna przed sędziami (III pótluneta)

U dołu obrazu inskrypcja komentująca: „Susanna, lieber wil verliehren Leib vnd Leben. Alß ihre keusche Ehr Durch böse Lust vergeben. / Drumb rettet Sie auch Gott durch Daniel den Knecht bringt vmb die falsche Zung vnd giebet der ihr Recht."

d. Chrystus i jawnogrzesznica (IV półluneta) - według ryciny Matthäusa Meriana z serii Icones Biblicae

Poniżej palca Chrystusa, piszącego na piasku, cytat z Nowego Testamentu: „Wer vnter euch ohne Sünde ist, / der werffe Den ersten Stein Auff sie. / Joh. VIII”. U dołu obrazu inskrypcja komentująca: „Begierig seynd alhie die Schrifft gelährte Pfaffen; Die Ehebrecherin $\mathrm{Zu}$ richten vnd $\mathrm{Zu}$ straffen. / Herr Christus giebt es $\mathrm{Zu}$, doch wo sie wurden seÿn Ohn fehler Balt der Pfaff das Richten stellet ein".

e. Sąd Salomona (V półluneta) - według kompozycji Rubensa i ryciny Boëtiusa a Bolswert

U dołu obrazu inskrypcja komentująca: „Ob gleich hie Salomon, ein schweres Urthel fellet. So wird Dennoch kein Theil mit vnrecht uber schnellet. / Es kompt vielmehr anß Licht wer recht die Mutter seÿ Das Kindt bleibt vnge Zweÿt Der streit geleget beÿ”.

f. Chrystus przed Pitatem (VI półluneta) - według ryciny Rembrandta (B. 77) U dołu obrazu inskrypcja komentująca: „O du verdamter Hauff, wie bistu so verwegen, Vnd spottest deinen Gott mit schnöden Backen schlägen / Sprichst noch, es treff sein Bluht, dich vnd dein gantz Geschlecht; Sie was du Hast gewunscht, das kompt dir eben recht".

g. Królowa Saby przed Salomonem (VII półluneta) - malowidło wykonane $\mathrm{z}$ udziałem warsztatu według ryciny Matthäusa Meriana z serii Icones Biblicae 
U dołu obrazu inskrypcja komentująca: „Die Weißheit Salomons, Pracht wunder Hohe Gaben Weit aus Arabien mit macht gelocket Haben. / Die reiche Königin, so ihm deswegen holdt, Auch mild beschencket hat mit Specereÿ vnd Goldt."

b. Grosz czynszowy (VIII półluneta) - malowidło wykonane z udziałem warsztatu według ryciny Rembrandta (B. 68)

$\mathrm{U}$ dołu obrazu fragmentarycznie zachowana inskrypcja komentująca: „Die Heuchler tragen hie ein Giftiges [?] [...] / Er aber fanget sie vnd lehrt wie [?] [...]".

Lit.: von Nottbeck/Neumann 1904, s. 189 n.; Hofstede de Groot 1906, s. 137, nr 109; Neumann 1908, s. 1; Peets/Johansen 1935, s. 8 n.; Vaga 1940, s. 45 n., il. 44; Gerson 1942/83, s. 496 n.; Campe 1957, s. 57; Художники народов 1970, s. 73; Брунс/Кангропооль 1971, s. 109; Eesti kunsti ajalugu 1975, s. 119 n., il. 330-331; История искусства 1976, s. 346, il. 340; Kunstdenkmäler 1992, s. 344; Savinova 1992; Brusewicz 1994, s. 62; Kodres 1994, s. 143, nr 14; Ehasalu 2002, s. 172 n., il. na s. 177 n., tabl. IV; Ehasalu 2004; Eesti kunsti ajalugu 2005, s. 74 n., il. 4; Ehasalu 2007, s. 294 n.

\section{Wykaz skrótów literatury cytowanej w katalogu}

Białostocki/Walicki 1956 - J. Białostocki, M. Walicki, Rembrandt i jego krag, kat. wyst., Muzeum Narodowe w Warszawie, 15 III-30 IV 1956.

Bogdanowicz 1995 - S. Bogdanowicz, Die Kathedrale zu Oliva, Dülmen 1995. Брунс/Кангропооль 1971 - А. Брунс, Р. Кангропооль, Талин. Художественные памятники XIII-XX веков, АенинграА 1971.

Brusewicz 1994 - L. Brusewicz, Zagadka tzw. Ecce Homo z kościota św. Piotra na Helu - studium recepcji sztuki Rembrandta w siedemnastowiecznej Rzeczypospolitej, „Acta Universitatis Nicolai Copernici, Zabytkoznawstwo i Konserwatorstwo", XXV, 1994.

Campe 1957 - P. Campe, Lexikon liv- und kurländischer Baumeister, Bauhandwerker und Baugestalter von 1400-1850, t. 2: Nachtrag und Ergänzung zum 1. Bande, Stockholm 1957.

Dehio 1906 - G. Dehio, Handbuch der deutschen Kunstdenkmäler, t. 1: Nordostdeutschland, Berlin 1906.

Dehio 1926 - G. Dehio, Handbuch der deutschen Kunstdenkmäler, t. 2: Nordostdeutschland, Berlin 1926. 
Dehio/Gall 1952 - G. Dehio, Handbuch der deutschen Kunstdenkmäler, nowe oprac. E. Gall, Deutschordensland Preußen, oprac. przy współpr. B. Schmid, G. Tiemann, München 1952.

Drost/Swoboda 1972 - W. Drost, Kunstdenkmäler der Stadt Danzig, t. 5: St. Trinitatis - St. Peter und Paul - St. Bartholomäi..., oprac. F. Swoboda, Stuttgart 1972.

Eesti kunsti ajalugu 1975 - Eesti kunsti ajalugu kahes köites, t. 1: Eesti kunst kõige varasemast ajast kuni 19. saj. keskpaigani, red. B. Bernstein, E. Jansen [i in.], Tallinn 1975.

Eesti kunsti ajalugu 2005 - Eesti kunsti ajalugu, t. 2: 1520-1770, oprac. i red. K. Kodres, [Tallinn] 2005.

Ehasalu 2002 - P. Ehasalu, Exempla docent ehk mõnda Tallinna raesaali pildiprorammist ja rootsiaegsetest portreedest, „Kunsti-teaduslikke uurimusi”, XI, 2002, s. 165 n.

Ehasalu 2004 - P. Ehasalu, Heast ja öiglasest valitsusest. Raesaali õigusemõistmise teemalised maalid, [w:] Tallinna Raekoda, red. I. Jürgenson, Tallinn 2004, s. $162 \mathrm{n}$.

Ehasalu 2007 - P. Ehasalu, Painting in Tallinn during the Swedish Period (1561-1710). Production and Reception. Doctoral Thesis, Estonian Academy of Arts, Institute of Art History, Tallinn 2007.

Gerson 1942/83 - H. Gerson, Ausbreitung und Nachwirkung der holländischen Malerei des 17. Jabrhunderts, Amsterdam 1983 (pierwodruk: Haarlem 1942). Gosieniecka 1957 - A. Gosieniecka, Malarstwo gdańskie XVI i XVII wieku, kat. wyst., Muzeum Pomorskie w Gdańsku, Gdańsk 1957.

Grzybkowska 1979 - T. Grzybkowska, Andrzej Stech malarz gdański, Warszawa 1979.

Guć-Jednaszewska 1992 - T. Guć-Jednaszewska, Dokumentacja i konserwacja zabytkowych dziet sztuki gdańskiej, [w:] Studia z historii sztuki Gdańska i Pomorza, Wrocław 1992 („Teka Gdańska”, II), s. 6 n.

Habela 1975 - J. Habela, Ratusz Staromiejski w Gdańsku, Wrocław 1975.

Habela 1986 - J. Habela, Ratusz Staromiejski w Gdańsku, Gdańsk 1986.

Heise 1884-87 - J. Heise, Die Bau- und Kunstdenkmäler der Provinz Westpreussen, t. 1: Pommerellen mit Ausnahme der Stadt Danzig, Danzig 1884-1887. Hirsch 1850 - Theodor Hirsch, Das Kloster Oliva. Ein Beitrag zur Geschichte der Westpreußischen Kunstbauten, Danzig 1850.

Hofstede de Groot 1906 - C. Hofstede de Groot, Die Urkunden über Rembrandt, Den Haag 1906.

Художники народов 1970 - Художники народов СССР. Биобиблиографический словарь, т. 1, Аавик-Бойко, орrac. О. Э. Вольценбург, Москва 1970. 
Iwicki 1994 - Z. Iwicki, Oliva. Führer durch die Kathedrale und das ehemalige Kloster, Dülmen 1994.

Iwicki 2001 - Z. Iwicki, Oliwa wczoraj i dziś. Przewodnik po zabytkach katedry i bytego klasztoru, Gdańsk 2001.

История искусства 1976 - История искусства народов СССР, т. 4: Искусство конща XVII-XVIII веков, red. А. Ю. Нурок, М. А. Ормовой, [Москва] 1976.

Kodres 1994 - K. Kodres, Tallinna maalijad 17. ja 18. sajandil, „Kunsti-teaduslikke uurimusi", VII, 1994, s. 134 n.

Kowalkowska 2009 - J. Kowalkowska, Strop ramowy z Sali Burmistrza w Ratuszu Staromiejskim w Gdańsku, Gdańsk 2009 [mps pracy licencjackiej pod kierunkiem dr. Jacka Kriegseisena, Katedra Historii Sztuki UG].

Kretzschmer 1847 - J. C. Kretzschmer, Geschichte und Beschreibung der Cisterzienser-Abtei Oliva, Danzig 1847.

Kunstdenkmäler 1992 - H.-J. Kubles, K. Alttroa [i in.], Kunstdenkmäler baltische Staaten, ein Bildhandbuch. Estland, Lettland, Litauen, Leipzig 1992.

Lingenberg 1986 - H. Lingenberg, Oliva - 800 Jahre. Von der Zisterzienserabtei zur Bischofskathedrale. Abriß der geschichte des klosters und Ortes Oliva (1186-1986), Lübeck 1986.

Mamuszka 1985 - F. Mamuszka, Oliwa. Okruchy z dziejów, zabytki, Gdańsk 1985. Mamuszka/Stankiewicz 1959 - F. Mamuszka, J. Stankiewicz, Oliwa. Dzieje i zabytki, Gdańsk 1959.

May 1925 - L. T. E. May, Festschrift zur Vierjahrhundertfeier der evangelischen Kirche und Gemeinde zu Hela, Hela 1925.

Neumann 1908 - Lexikon baltischer Künstler, red. W. Neumann, Riga 1908. von Nottbeck/Neumann 1904 - E. von Nottbeck, W. Neumann, Geschichte und Kunstdenkmäler der Stadt Reval, t. 2, Die Kunstdenkmäler der Stadt Reval, Reval 1904.

Peets/Johansen 1935 - H. Peets, P. Johansen, Tallinna raekoda, Tallinn 1935.

Rostworowski 1969 - M. Rostworowski, Pamięci Rembrandta - wystawa malarstwa polskiego w trzechsetna rocznice śmierci artysty, Muzeum Narodowe w Krakowie, Oddział - Zbiory Czartoryskich, XII 1969.

Savinova 1992 - E. Savinova, Aken, Johann (van ?), [w:] Saur allgemeines Künstler -Lexikon. Die bildenden Künstler aller Zeiten und Völker, t. 1: A-Alanson, München 1992, s. 700.

Schmidt 1901 - P. T. Schmidt, Die St.Trinitatis-Kirche zu Danzig nach Vergangenheit und Gegenwart, Danzig 1901.

Schmidt 1925 - A. Schmidt, Danziger merkwürdige Inschriften, „Heimatblätter des Deutschen Heimatbundes Danzig”, II, 1925, z. 2. 
Schwartz 1985 - G. Schwartz, Rembrandt, His Life, His Paintings: a New Biography, Harmondsworth 1985.

Vaga 1940 - V. Vaga, Eesti kunst, Tallinn 1940.

Valentiner 1957 - W. R. Valentiner, Rembrandt and Spinoza. A Study of the Spiritual Conflicts in Seventeenth Century Holland, London 1957.

\section{jacek Tylicki}

Johann Aken - a forgotten painter of the Baltic region and his works - summary

The paper deals with a $17^{\text {th }}$ painter, active in the Baltic area, that was until now virtually unknown outside Estonia. In the Tallinn town hall there exists a locally renowned cycle of paintings made by Johann Aken with an assistant and signed by him in 1667 . The biblical scenes, illustrating examples of burgher and Christian virtue and extolling good government, are remarkably largely based on prints after two great Netherlanders - Rembrandt and Rubens, apart from the popular graphic work of Matthäus Merian. This reaching out to Rembrandt's oeuvre for artistic patterns in an outlying region was noticed as early as 1906 by Cornelis Hofstede de Groot, who spotted the same phenomenon with regard to a large Ecce Homo painting, dated 1647, in a village church in Hela (Hel), now in the National Museum in Gdańsk (Danzig): the picture is based on Rembrandt's Christ before Pilate etching. Neither this scholar, however, nor his followers, linked the Tallinn and Gdańsk compositions to one another.

Estonian researchers managed to unearth, in time, an extensive judicial document from 1663, concerning Aken's imputed bigamy, which was eventually proven false. Sideline information from the source discloses the painter worked in Reval (Tallinn) since early 1662, but came from Danzig. This, in turn, led the author of the present paper to compare the Tallinn city hall works with the one in Gdańsk: it seems that apart from some minor differences, perhaps in part resulting from later overpainting, all these works were made by the same hand. Identical average quality painterly handling, representation of somewhat puppetlike human figures and an interest towards depicting architecture settings - both a bit erroneous as far as anatomy and perspective is concerned - are discernible in some other pictures preserved in Gdansk and its whereabouts. These include a Return of the Prodigal Son in St. Anne's chapel (c. 1650), a ceiling consisting 
of nine paintings from a burgher's house, now in Old Town City Hall (1642 ?), and a Visitation, altar retable in the cathedral church in Gdańsk-Oliwa (1645). Especially the latter two show in some details considerable proximity with the Tallinn cycle, and all of these works are again mostly based on Netherlandish prints, including some by Rembrandt and some after Rubens.

No archival evidence on Aken seems to have survived in Gdańsk, this proving, however, that the artist was not a guild member there. Nonetheless, further discovered sources inform he appeared in Lübeck in 1656, baptizing there his son, and was buried in St. Peter's church in Riga in 1689. The decision to move to the former town was probably made in order to escape a major PolishSwedish war that began in 1655 . In any case, neither in Lübeck, nor in today's Latvia any traces of his further activity may be found.

This first attempt to produce a more general biographical sketch of Johann Aken, who was most probably born c. 1610, still leaves open two important questions. First, whether he was a Netherlander by descent, as suggested in literature (at one point, his Gdańsk 'Ecce Homo' panel was attributed to a Dutchman, Helmich van Twenhuysen), and second - this issue tied to the former - why did he choose so many then recent and very novel graphic patterns by Rembrandt to produce his thematically typical and artistically average pictures current in the region of Europe where he practiced his proffesion. 


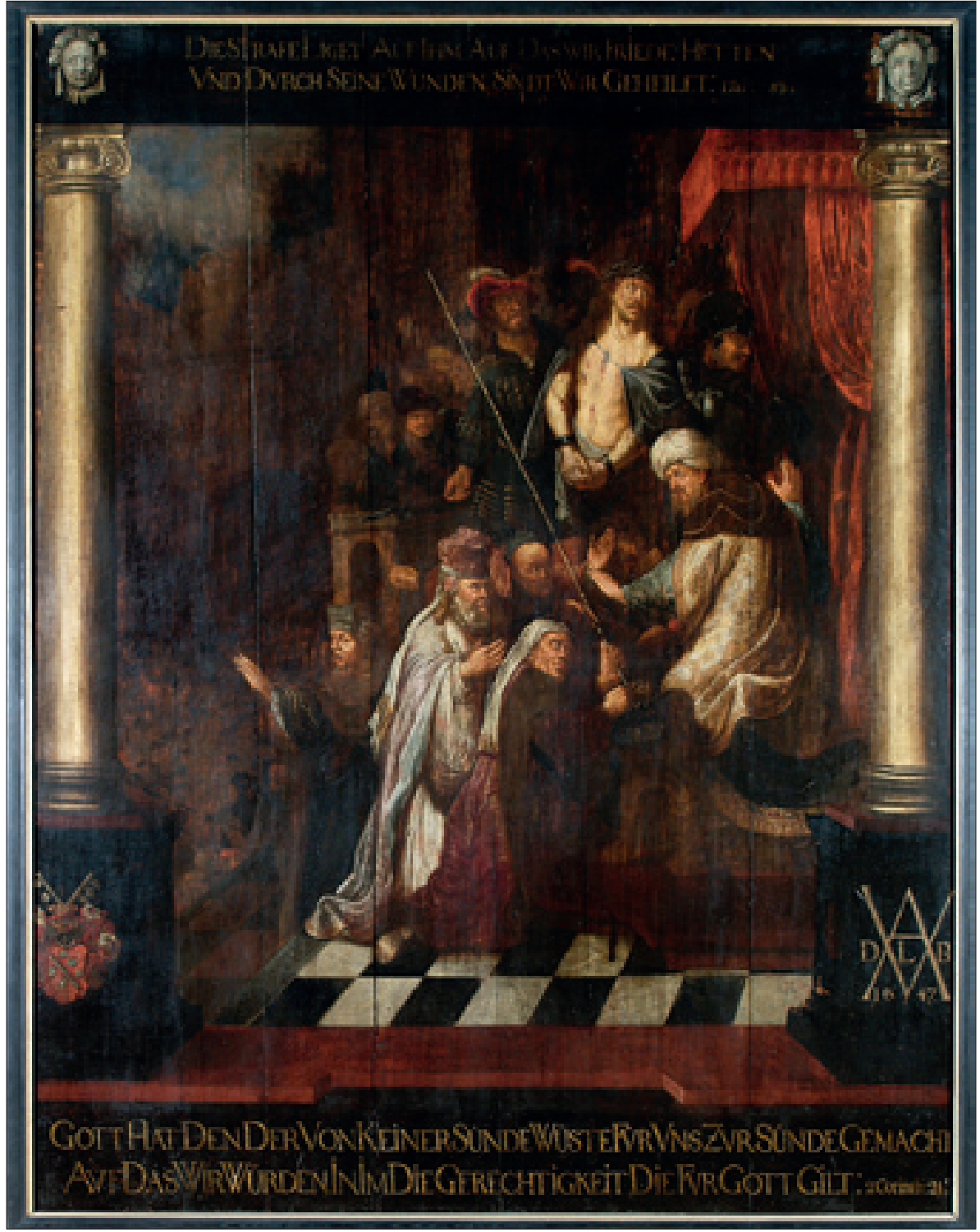

Ilustracja 1

Johann Aken, Ecce Homo, 1647. W zbiorach Muzeum Narodowego w Gdańsku. Fot. Pracownia Reprograficzna MNG 


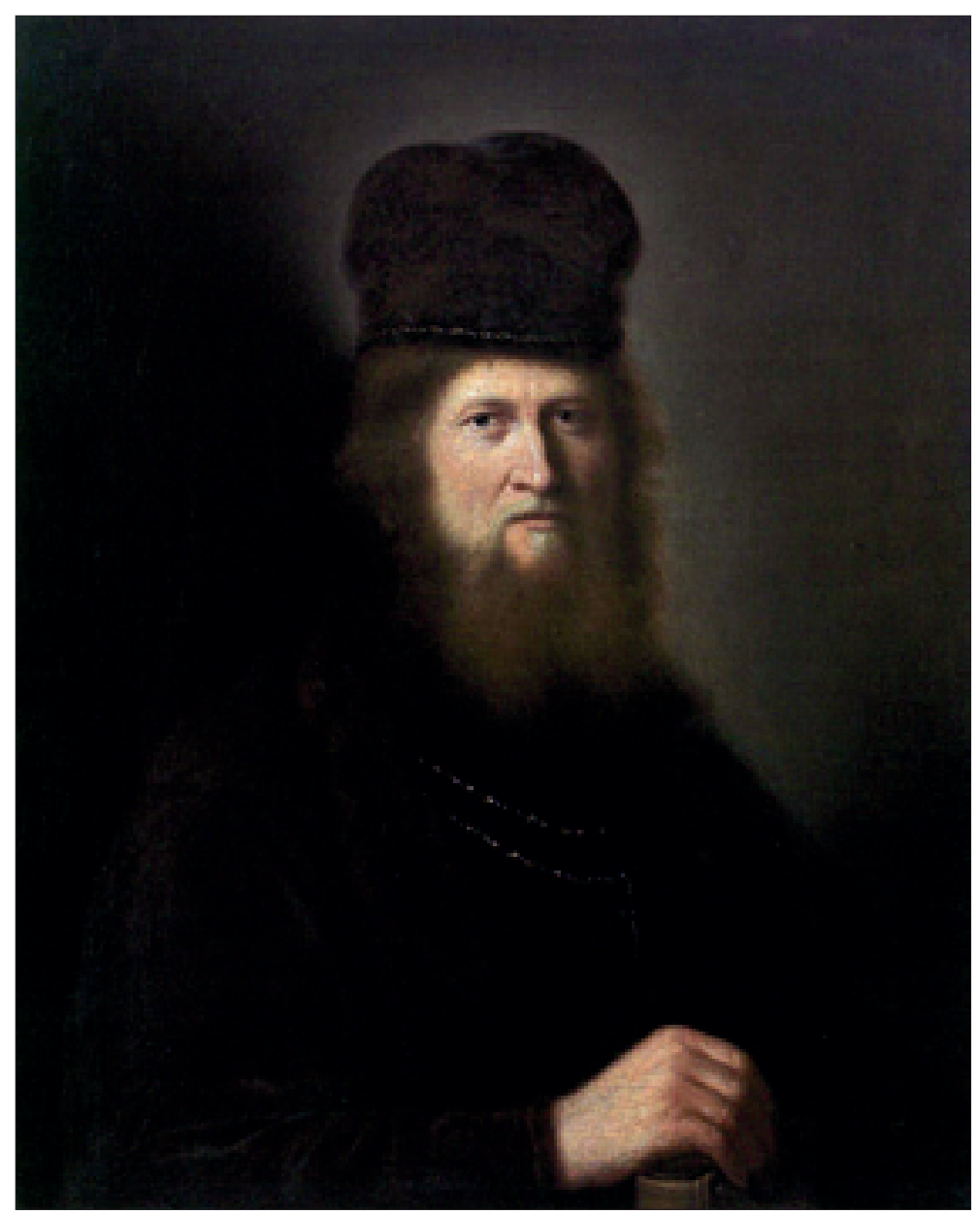

Ilustracja 2

Helmich van Twenhuysen, Portret brodatego mężczyzny $w$ czapce. W zbiorach Muzeum Narodowego we Wrocławiu. Fot. E. Witecki 


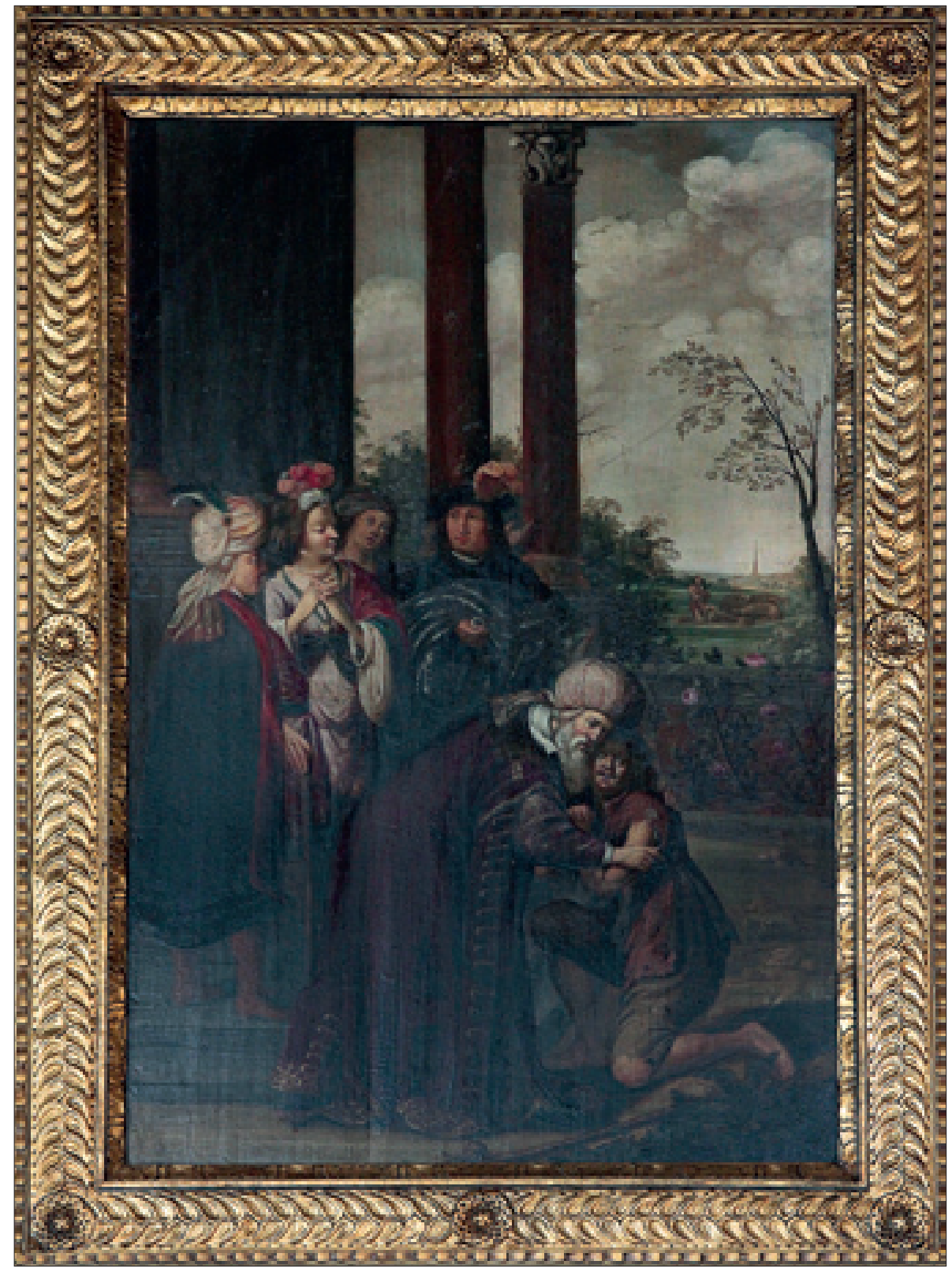

\section{Ilustracja 3}

Johann Aken, Powrót syna marnotrawnego, ok. 1650, kaplica św. Anny w Gdańsku. Fot. D. Kula 


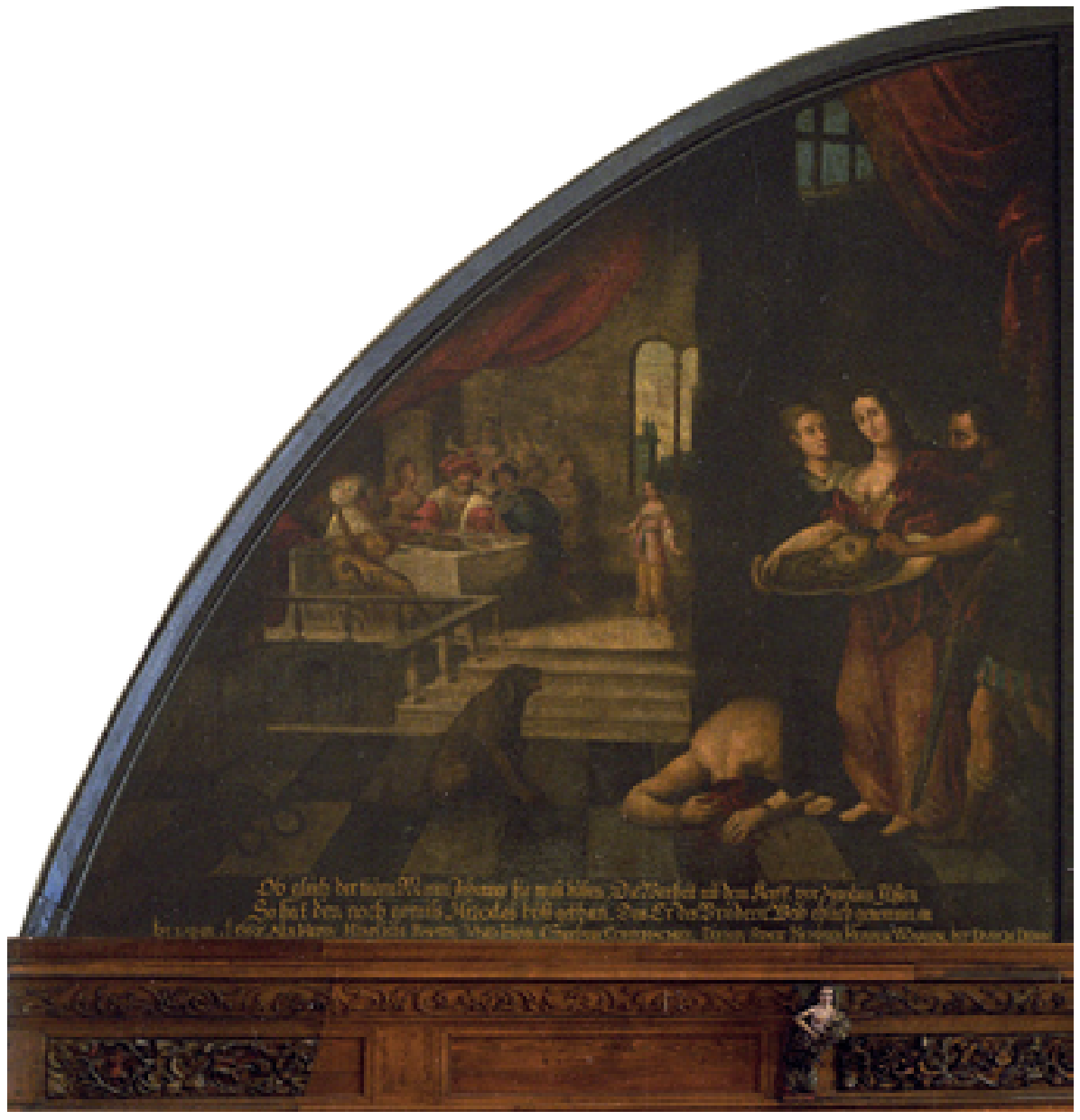

Ilustracja 4

Johann Aken, Herodiada z gtowa św. Jana Chrzciciela, 1667, Sala Rady w ratuszu w Tallinie. Fot. J. Heinla (Photoarchive of the Conservation Centre Kanut - Tallinn) 


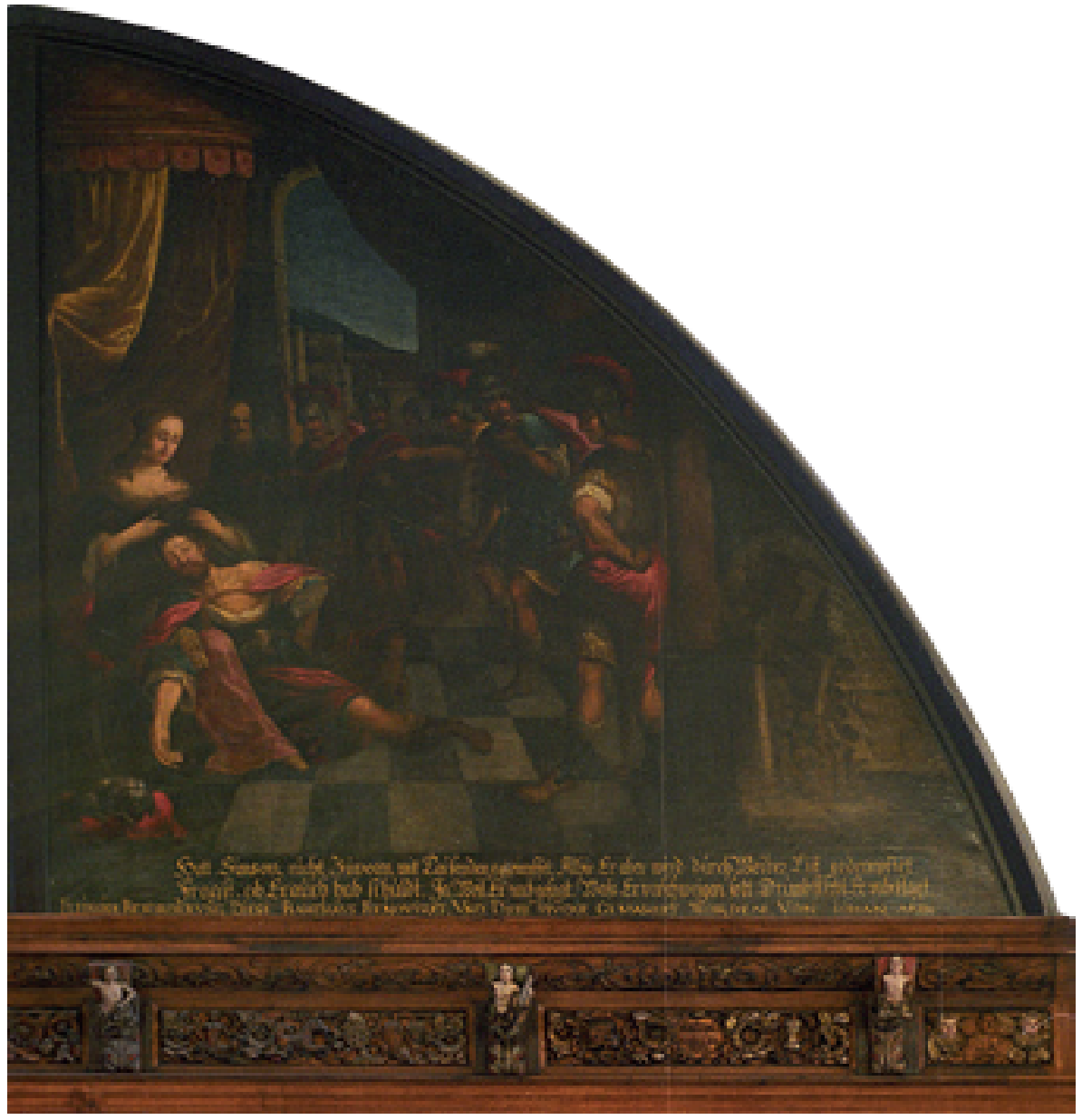

Ilustracja 5

Johann Aken, Samson i Dalila, 1667, Sala Rady w ratuszu w Tallinie. Fot. J. Heinla (Photoarchive of the Conservation Centre Kanut - Tallinn) 


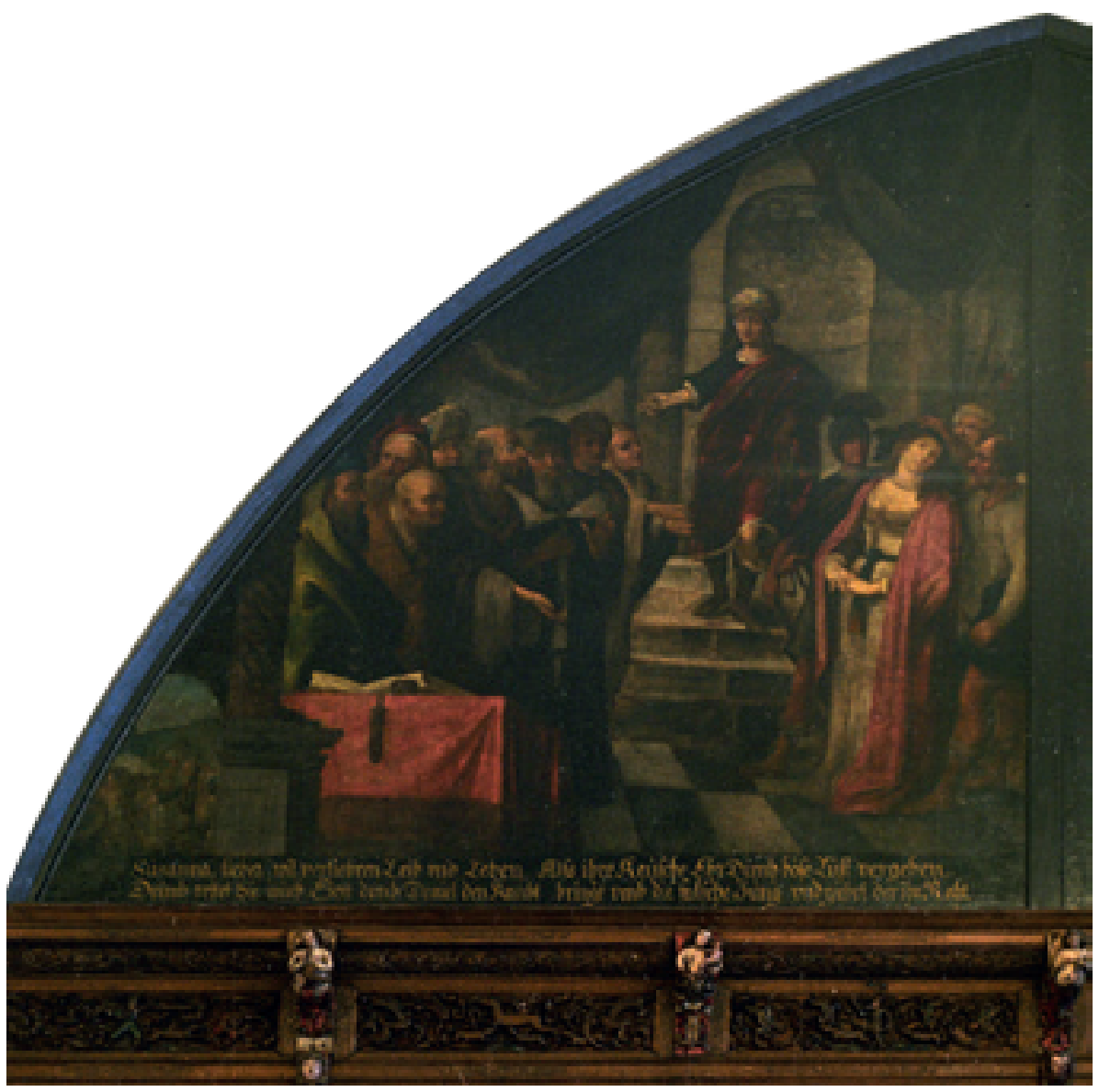

Ilustracja 6

Johann Aken, Zuzanna przed sędziami, 1667, Sala Rady w ratuszu w Tallinie. Fot. J. Heinla (Photoarchive of the Conservation Centre Kanut - Tallinn) 


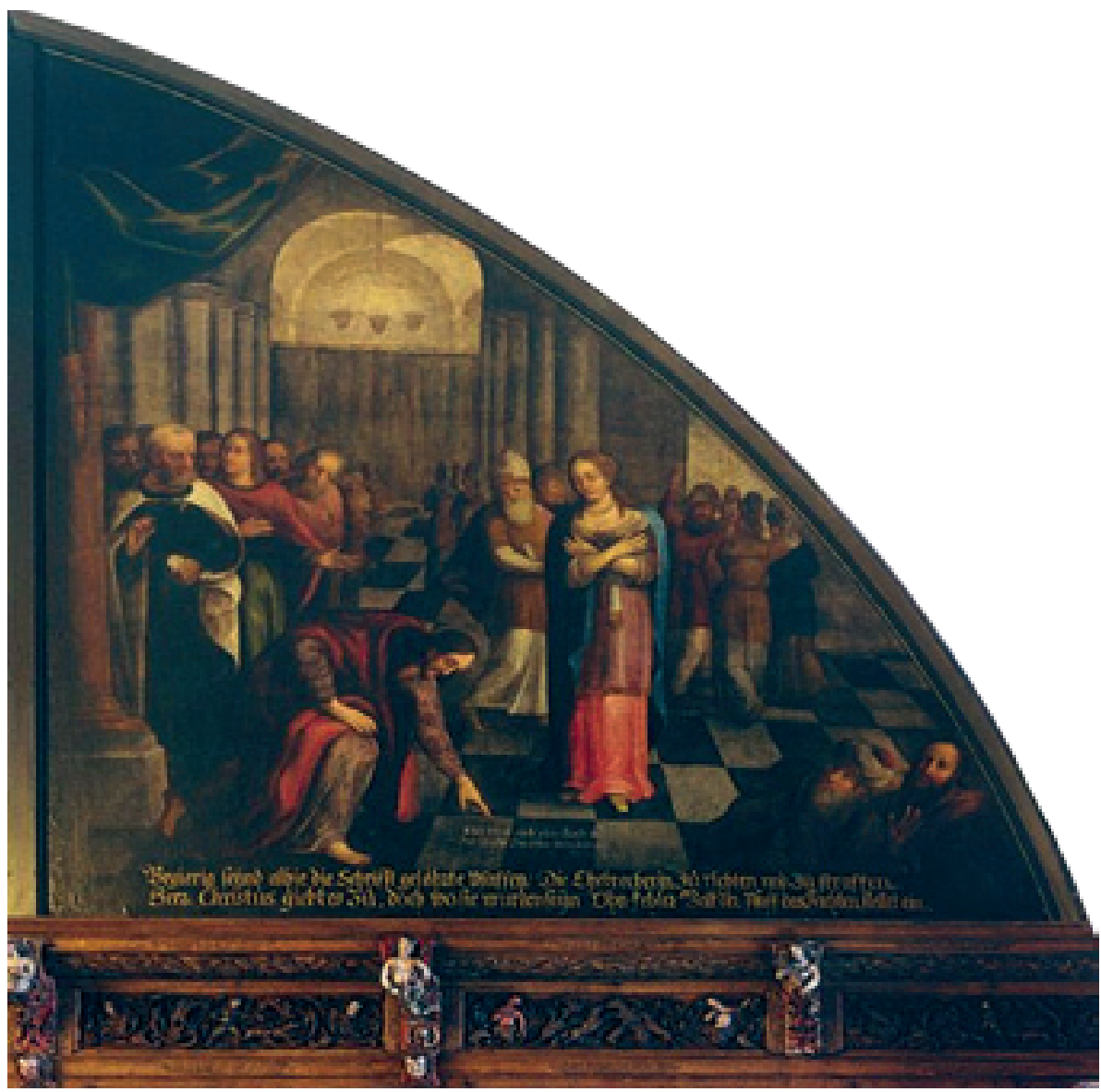

Ilustracja ?

Johann Aken, Chrystus i jawnogrzesznica, 1667, Sala Rady w ratuszu w Tallinie. Fot. J. Heinla (Photoarchive of the Conservation Centre Kanut - Tallinn) 


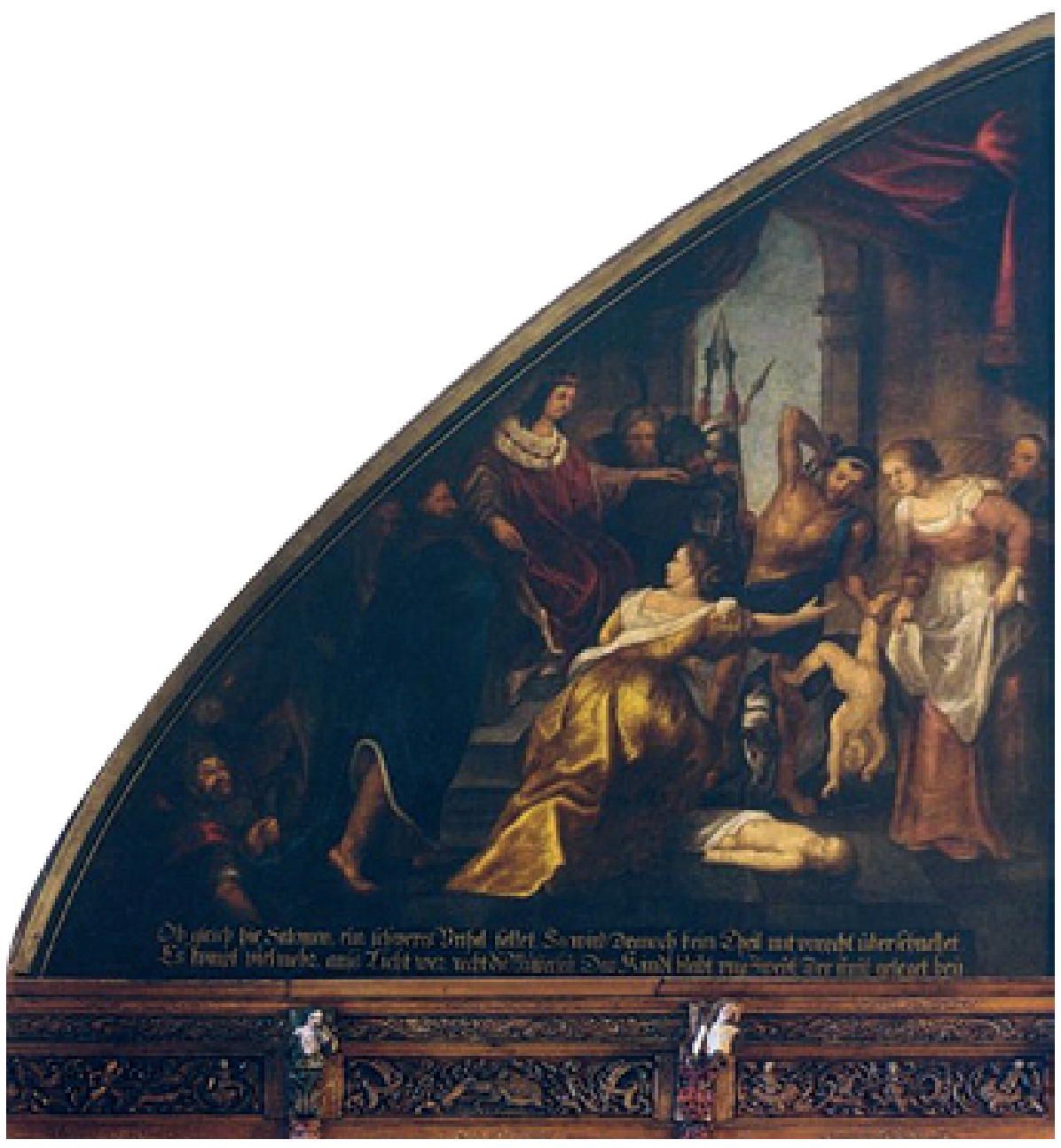

Ilustracja 8

Johann Aken, Sąd Salomona, 1667, Sala Rady w ratuszu w Tallinie. Fot. J. Heinla (Photoarchive of the Conservation Centre Kanut - Tallinn) 


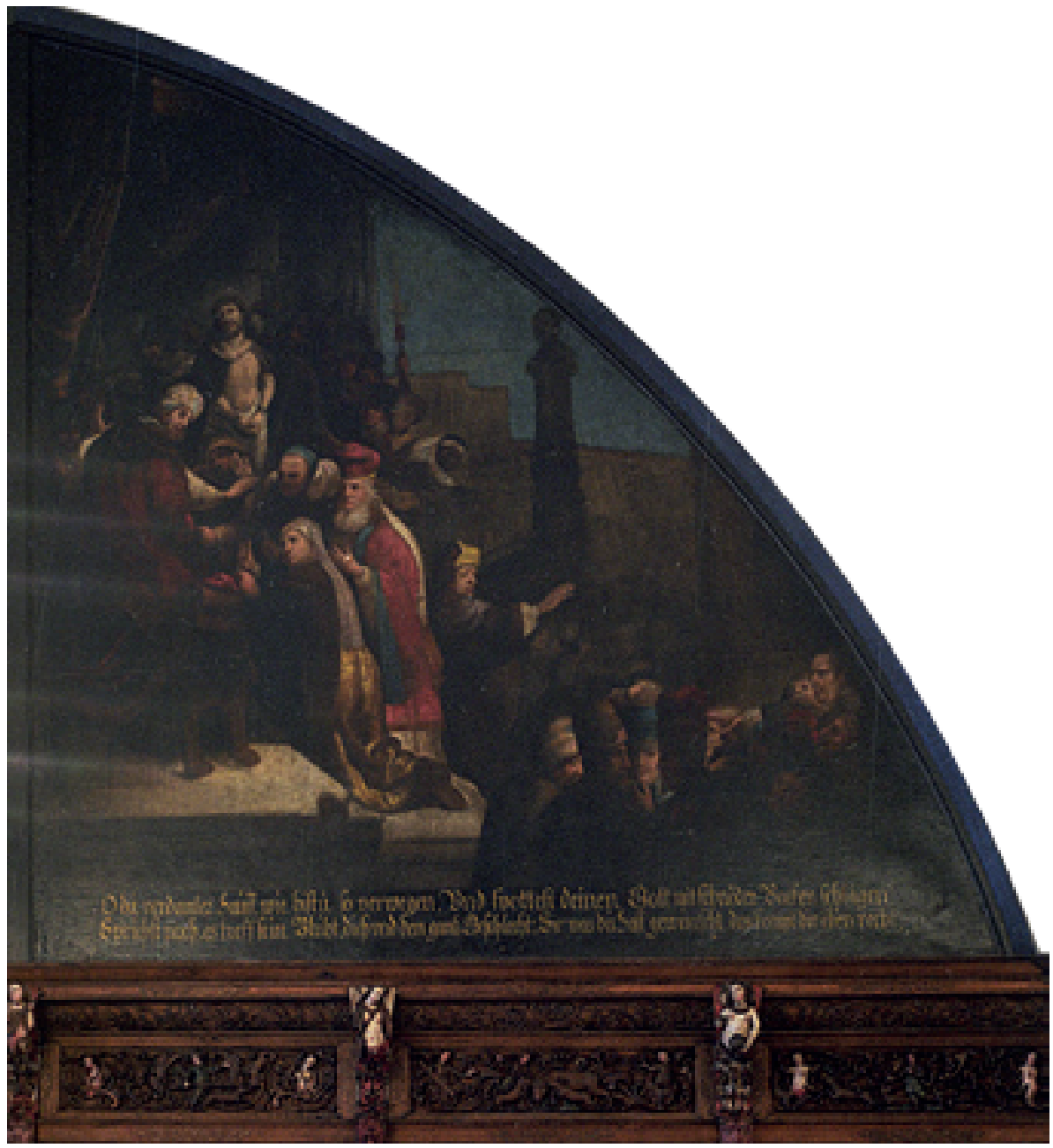

Ilustracja 9

Johann Aken, Chrystus przed Pitatem, 1667, Sala Rady w ratuszu w Tallinie. Fot. J. Heinla (Photoarchive of the Conservation Centre Kanut - Tallinn) 


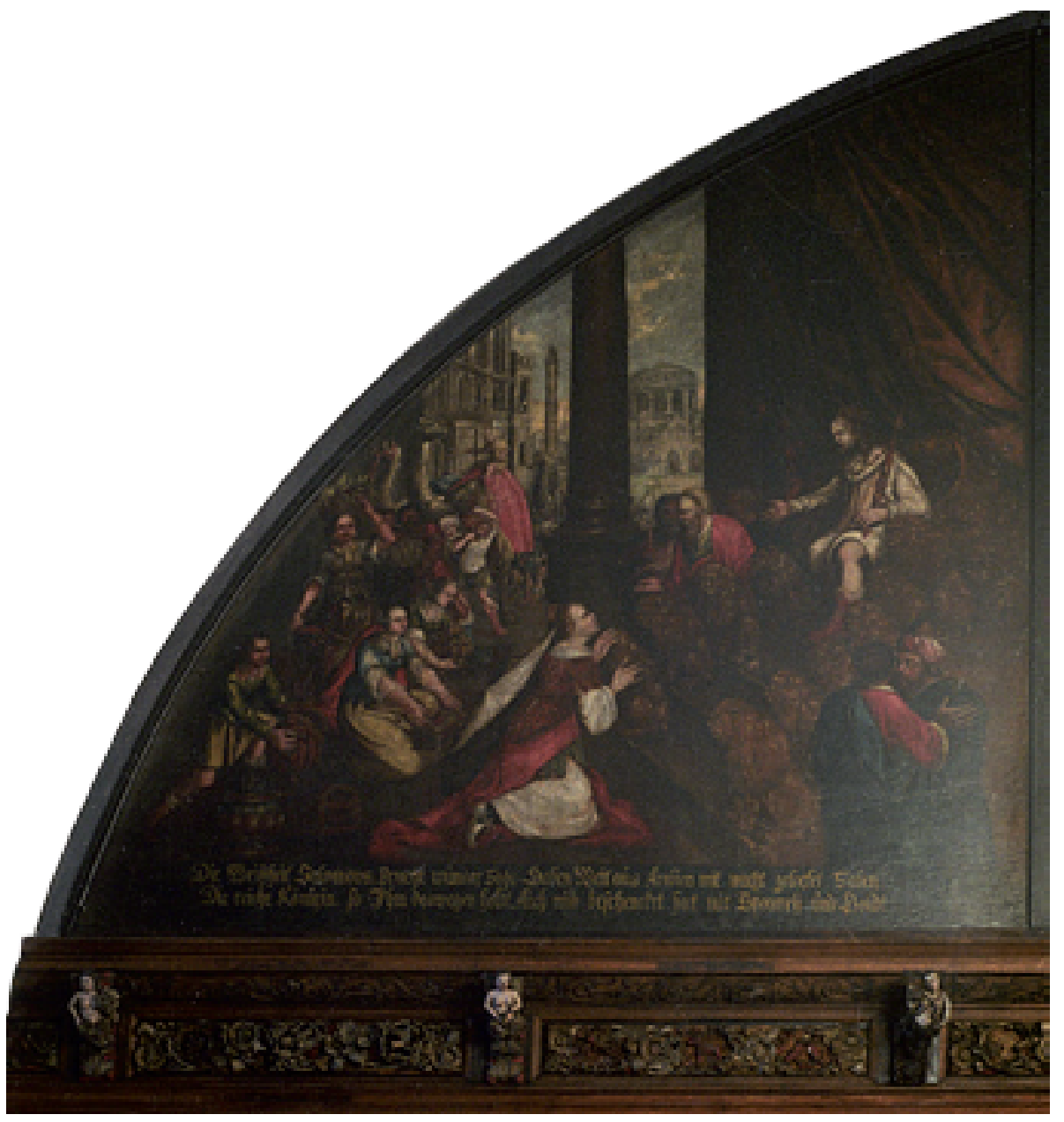

Ilustracja 10

Johann Aken z pracownią, Królowa Saby przed Salomonem, 1667, Sala Rady w ratuszu w Tallinie. Fot. J. Heinla (Photoarchive of the Conservation Centre Kanut - Tallinn) 


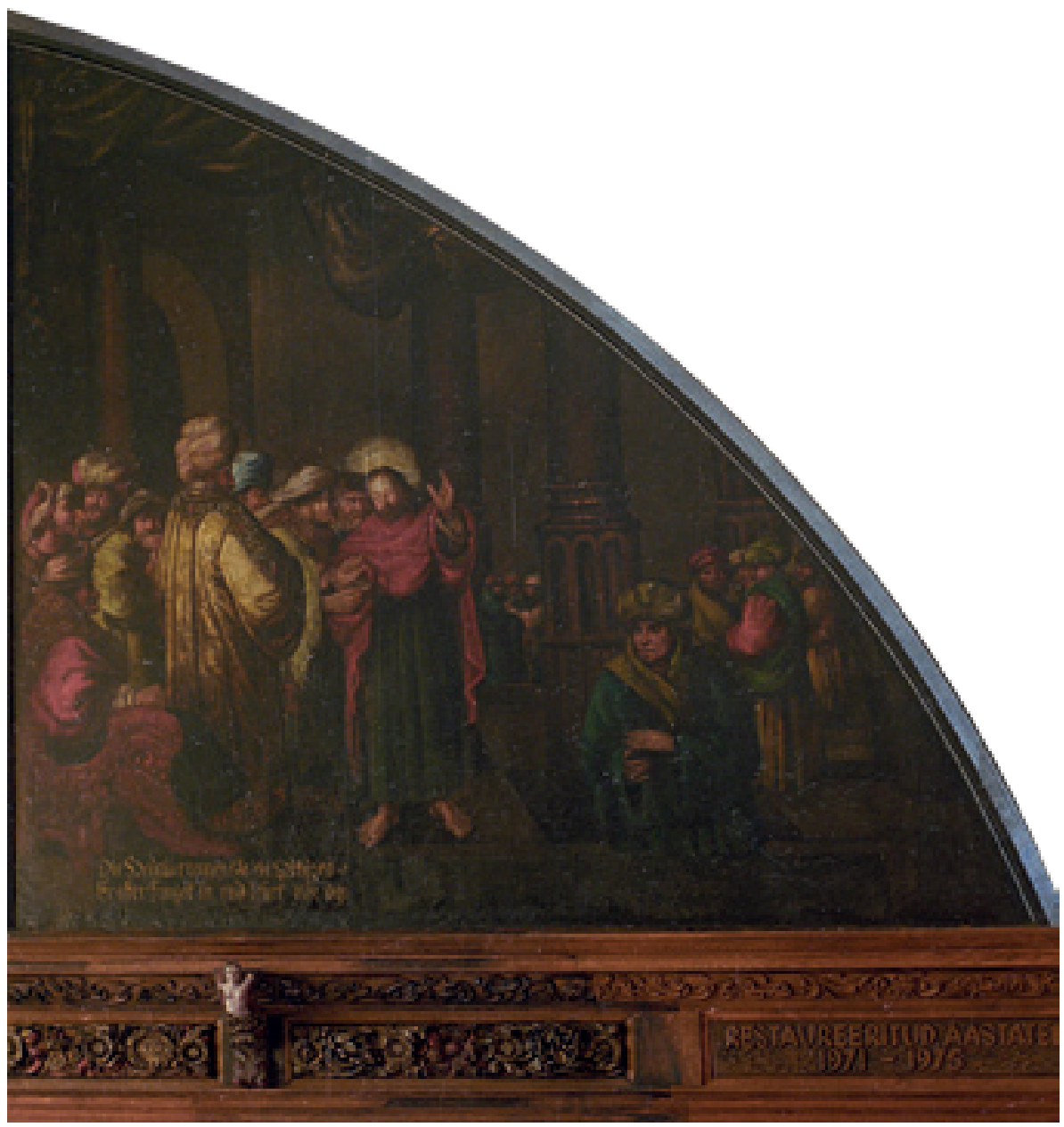

Ilustracja 11

Johann Aken z pracownią, Grosz czynszowy, 1667, Sala Rady w ratuszu w Tallinie. Fot. J. Heinla (Photoarchive of the Conservation Centre Kanut - Tallinn) 


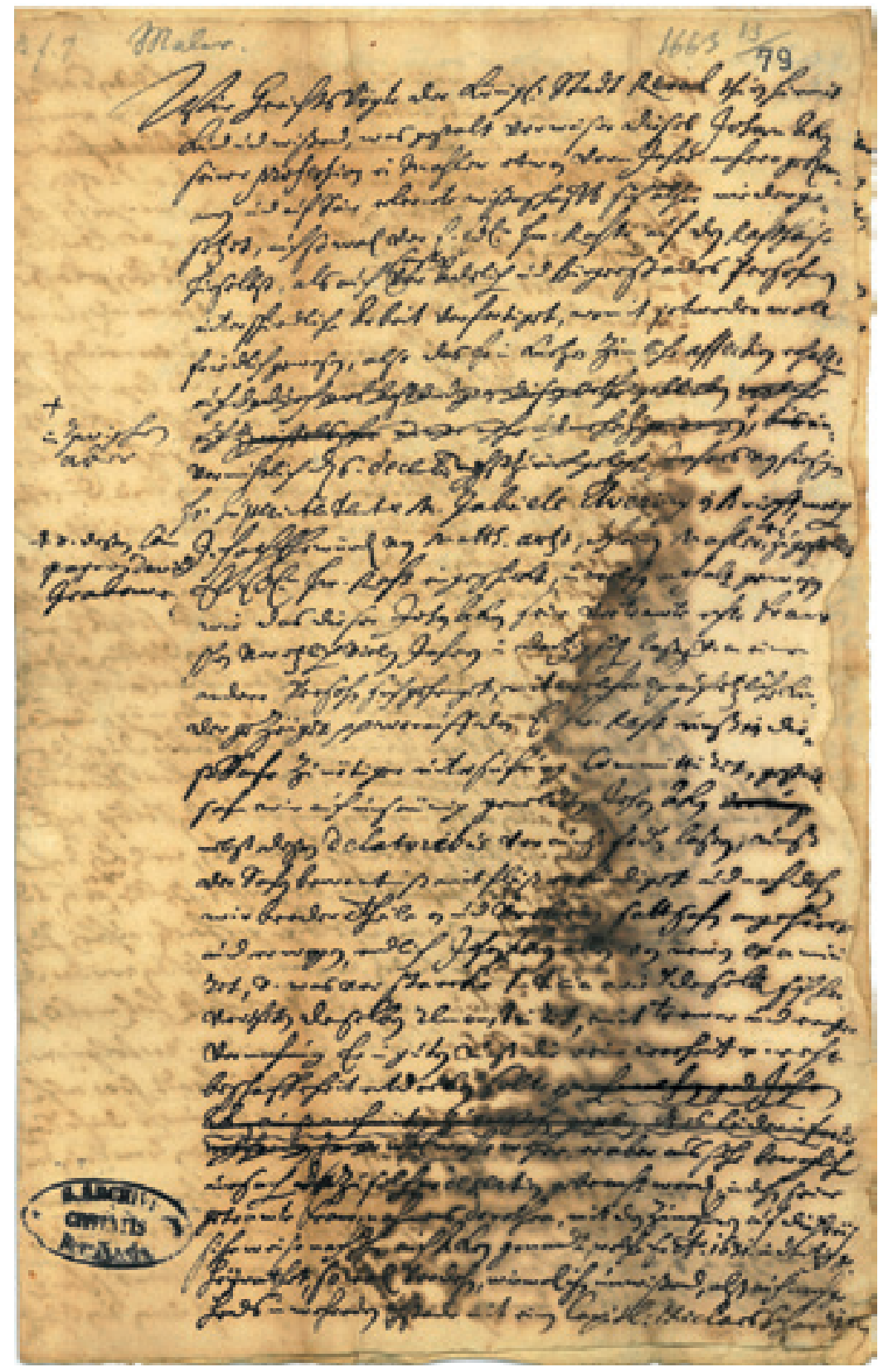

Ilustracja 12

Pierwsza strona dokumentu sądu wójtowskiego w Rewalu, dotyczącego malarza Johanna Akena, 1663. w zbiorach Tallinna Linnaarhiiv, sygnatura: Bf 33-III (fragment). Fot. Pracownia Reprograficzna TL 


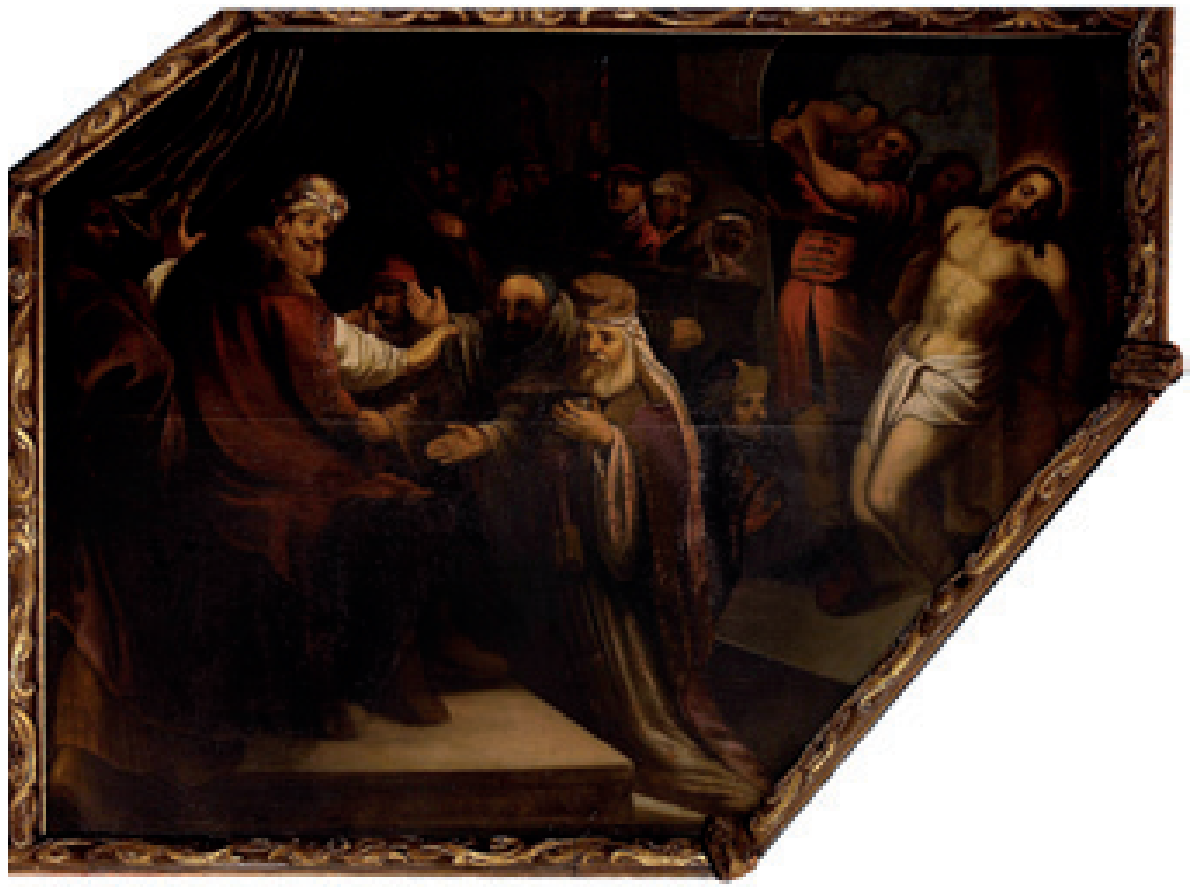

Ilustracja 13

Johann Aken, Skazanie Chrystusa na śmierć, 1642 (?), z malowideł stropowych w domu Fichtlów, Ratusz Staromiejski w Gdańsku. Fot. M. Janus 


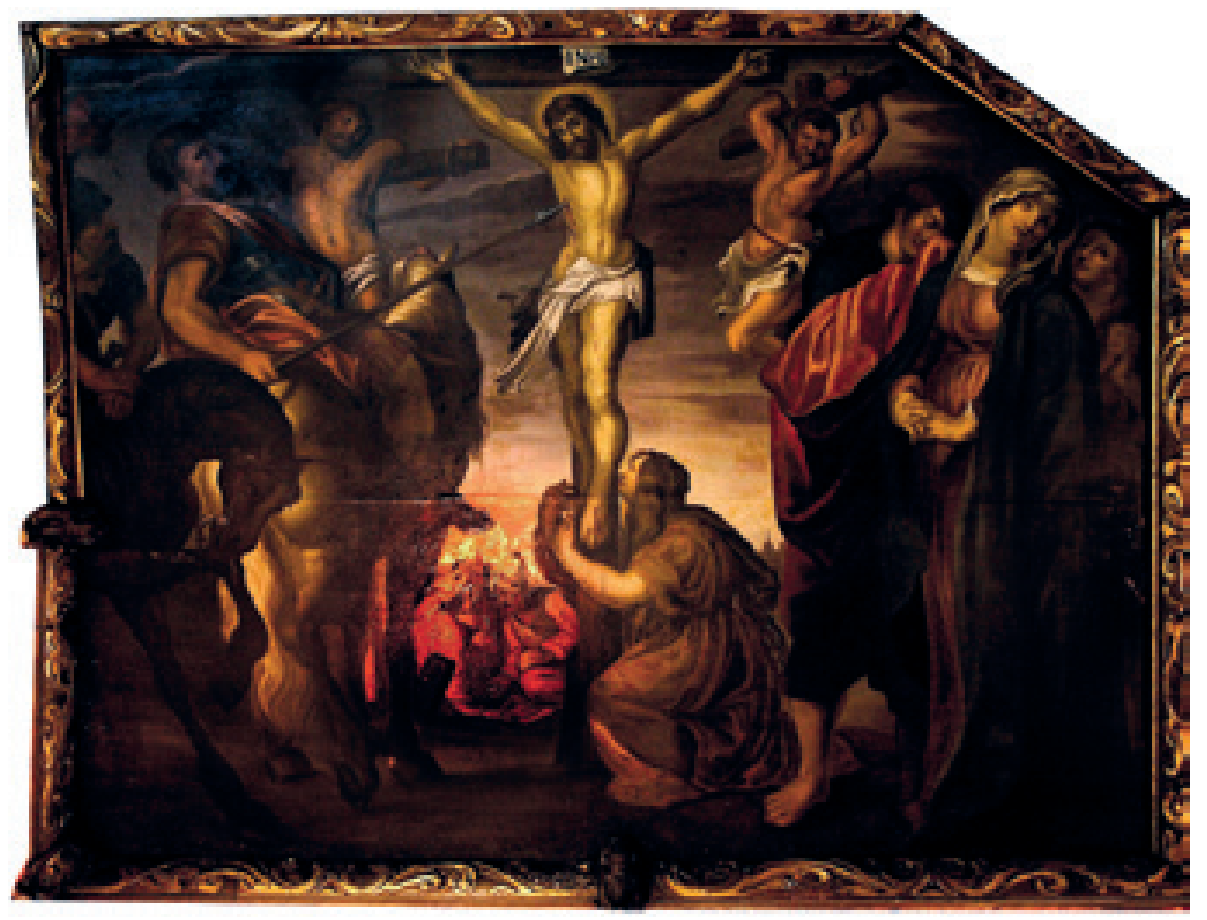

Ilustracja 14

Johann Aken, Śmierć Chrystusa na krzyżu, 1642 (?), z malowideł stropowych w domu Fichtlów, Ratusz Staromiejski w Gdańsku. Fot. M. Janus 


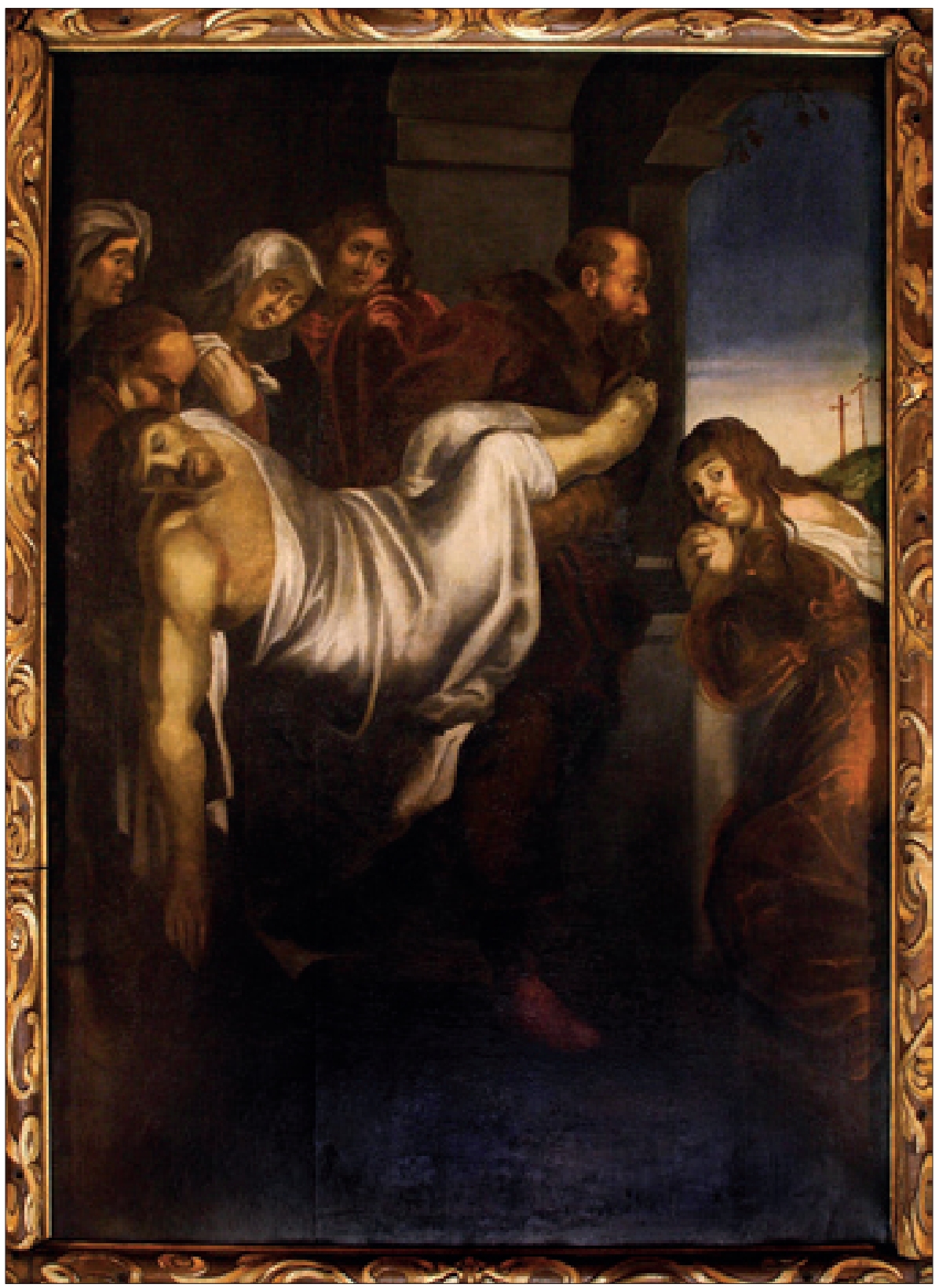

\section{Ilustracja 15}

Johann Aken, Ztożenie Chrystusa do grobu, 1642 (?), z malowideł stropowych w domu Fichtlów, Ratusz Staromiejski w Gdańsku. Fot. M. Janus 


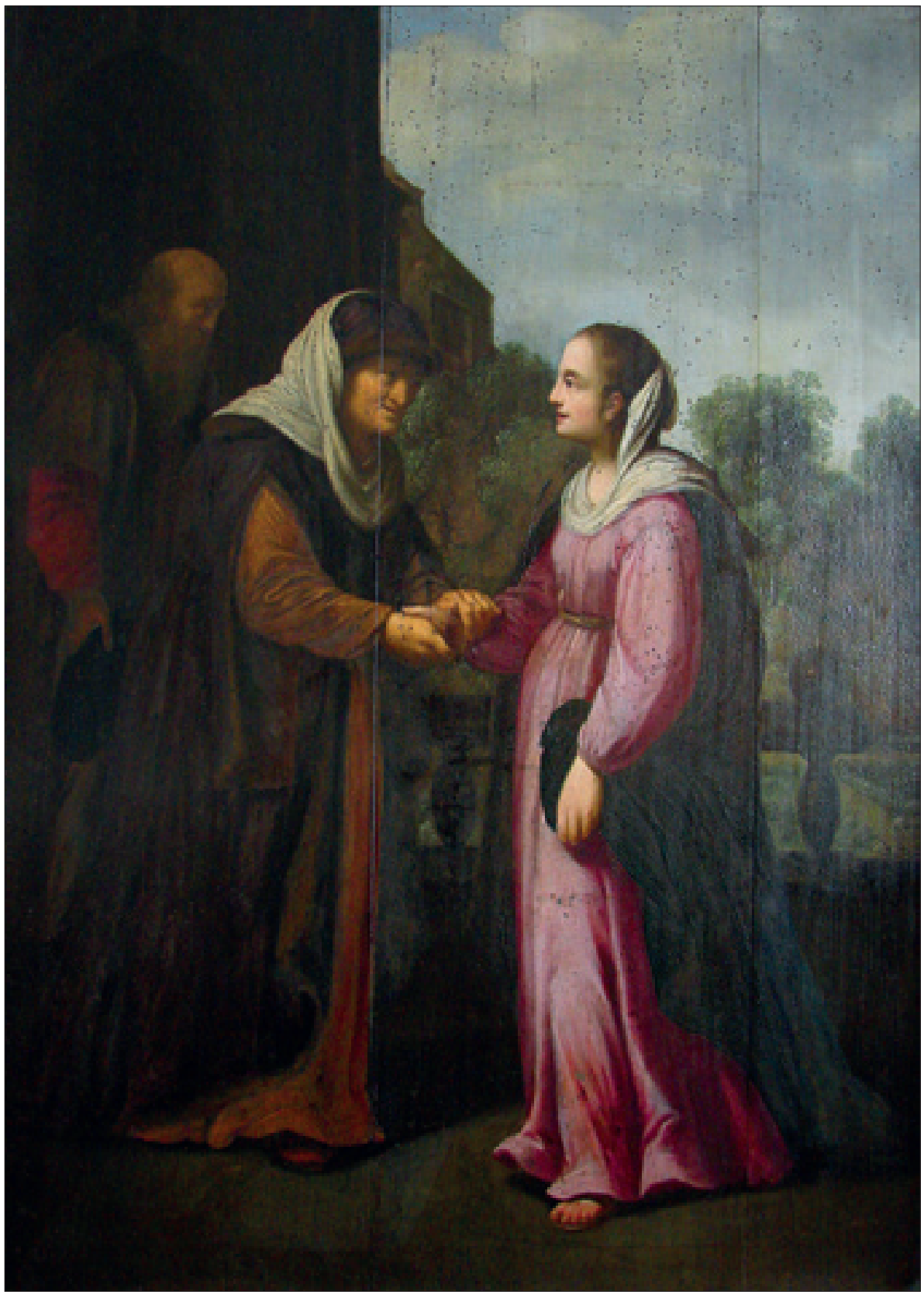

Ilustracja 16

Johann Aken, Nawiedzenie św. Elżbiety, 1645, ołtarz Czterech Doktorów Kościoła (retabulum), katedra w Gdańsku-Oliwie. Fot. S. M. Sangar 